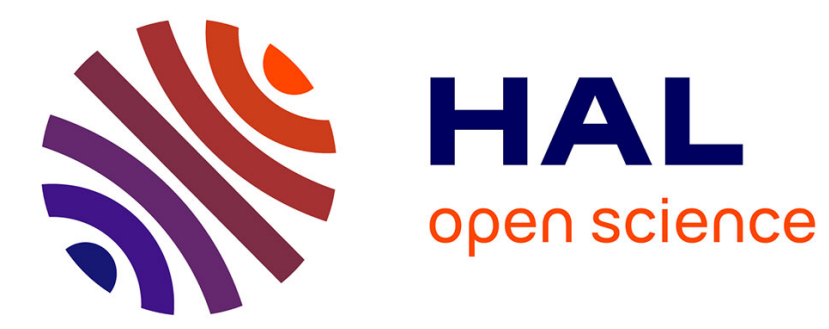

\title{
Diastereoselective Synthesis of Nonplanar 3-Amino-1,2,4-oxadiazine Scaffold: Structure Revision of Alchornedine
}

Shuang-Qi Tang, Maeva Leloire, Severine Schneider, Julie Mohr, Jacques

Bricard, Patrick Gizzi, Delphine Garnier, Martine Schmitt, Frédéric Bihel

\section{To cite this version:}

Shuang-Qi Tang, Maeva Leloire, Severine Schneider, Julie Mohr, Jacques Bricard, et al.. Diastereoselective Synthesis of Nonplanar 3-Amino-1,2,4-oxadiazine Scaffold: Structure Revision of Alchornedine. Journal of Organic Chemistry, In press, 10.1021/acs.joc.0c01764 . hal-03021041

\section{HAL Id: hal-03021041 \\ https://hal.science/hal-03021041}

Submitted on 24 Nov 2020

HAL is a multi-disciplinary open access archive for the deposit and dissemination of scientific research documents, whether they are published or not. The documents may come from teaching and research institutions in France or abroad, or from public or private research centers.
L'archive ouverte pluridisciplinaire HAL, est destinée au dépôt et à la diffusion de documents scientifiques de niveau recherche, publiés ou non, émanant des établissements d'enseignement et de recherche français ou étrangers, des laboratoires publics ou privés.

\section{(c) (1) $\$$}

Distributed under a Creative Commons Attribution - NonCommerciall 4.0 International 


\title{
Diastereoselective synthesis of non-planar 3-amino-1,2,4- oxadiazine scaffold: structure revision of alchornedine
}

\author{
Shuang-Qi Tang, ${ }^{[a]}$ Maeva Leloire, ${ }^{[a]}$ Séverine Schneider, ${ }^{[a]}$ Julie Mohr, ${ }^{[a]}$ Jacques Bricard, ${ }^{[a]}$ Patrick \\ Gizzi, ${ }^{[b]}$ Delphine Garnier, ${ }^{[c]}$ Martine Schmitt, ${ }^{[a]}$ and Frédéric Bihel ${ }^{*[a]}$ \\ [a] Laboratoire d'Innovation Thérapeutique, Labex Médalis, UMR7200, CNRS, Université de Strasbourg, Faculty of Pharmacy, 74 Route du Rhin, 67401 \\ Illkirch-Graffenstaden, France \\ [b] PCBIS, UMS3286, CNRS, Université de Strasbourg, ESBS, Pôle API, 300 Bd Sébastien Brant, 67400 Illkirch-Graffenstaden, France \\ [c] Plateforme d'Analyse Chimique de Strasbourg-Illkirch, Université de Strasbourg, Faculty of Pharmacy, 74 Route du Rhin, 67401 Illkirch-Graffenstaden, \\ France \\ *Corresponding author: fbihel@unistra.fr
}

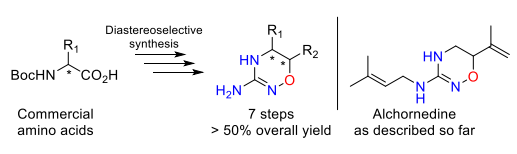

\begin{abstract}
Herein we report the diastereoselective synthesis of a 3-amino-1,2,4-oxadiazine (AOXD) scaffold. The presence of a N-O bond in the ring prevents the planar geometry of the aromatic system and induces a strong decrease in the basicity of the guanidine moiety. While DIBAL-H appeared to be the most efficient reducing agent because it exhibited high diastereoselectivity, we observed various behaviors of the Mitsunobu reaction on the resulting $\beta$-aminoalcohol, leading to either inversion or retention of configuration depending on the steric hindrance in the vicinitude of the hydroxy group. The physicochemical properties $\left(p K_{\mathrm{a}}\right.$, and $\left.\log \mathrm{D}\right)$ and hepatic stability of several AOXD derivatives were experimentally determined and found that the AOXD scaffold possesses promising properties for drug development. Moreover, we synthesized alchornedine, the only natural product with the AOXD scaffold. Based on a comparison of the analytical data, we found that the reported structure of alchornedine was incorrect and hypothesized a new one.
\end{abstract}

\section{INTRODUCTION}

Limitations in solubility, pharmacokinetics, and bioavailability of highly aromatic molecules have been well recognized; ${ }^{1}$ the medicinal chemistry community has become increasingly aware of the requirement to create drug-like compounds containing saturated building blocks. ${ }^{2-4}$ Among them, the six-membered heterocycle oxadiazines containing one oxygen and two nitrogen atoms have been considered as important skeletons because of their interesting potential in organic and medicinal chemistry. ${ }^{5-10}$ Unlike their aromatic triazine counterparts, the bivalent character of the oxygen atom endows oxadiazines with an interesting nonaromatic and non-planar geometry which has recently been highlighted and utilized in drug discovery through the concept of "escape from flatland" developed by F. Lovering et al. ${ }^{11,12}$

Among the different types of oxadiazines classified on the basis of the positions of their heteroatoms, we focused our work on the 3- amino-1,2,4-oxadiazine (AOXD) scaffold (Figure 1). This scaffold is particularly interesting because it presents two stereogenic $\mathrm{sp}^{3}$ centers; the presence of the bivalent oxygen atom in the a-position of the guanidine moiety affects $p K_{a}$ strongly decreasing the basicity of the guanidine moiety. This alkoxy-guanidine moiety is well known in its acyclic form in the natural amino acid L-canavanine, which possesses arginine antimetabolite property and is synthesized by leguminous plants. ${ }^{13}$ However, to date, only one natural product has been reported that consists of the cyclic form of AOXD. This natural guanidine-based alkaloid, alchornedine (Figure 1), was isolated from the leaves of Alchornea glandulosa and structurally identified by Barrosa et al in 2014. ${ }^{14}$ The authors also showed that alchornedine displayed antiprotozoal activity against Trypanosoma cruzi (Y strain). However, the total synthesis of this compound has not been reported yet, limiting the optimization of its activity against American trypanosomiasis.

Because of its distinctive structure and properties, general synthetic methods for chiral AOXD using readily available reagents are desirable. Although several preparative methods have been described for 3-alkyl/aryl-1,2,4-oxadiazines, ${ }^{15-17}$ the synthesis of chiral AOXD, to our knowledge, has not been reported.<smiles>C=C(C)C1CNC(NCC=C(C)C)=NO1</smiles>

alchornedine 1 (structure proposed based on NMR of isolated product)

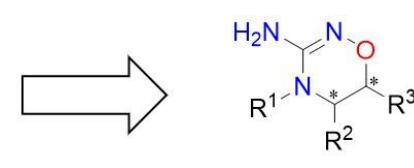

3-amino-1,2,4-oxadiazine (AOXD)

new scaffold for drug design physicochemical properties unknown
Figure 1. Alchornedine, the only natural product reported with a 3-amino1,2,4-oxadiazine scaffold.

In this study, we established a general synthetic method to access chiral AOXD by using readily available $\mathrm{N}$-Boc-amino acids as starting materials. The first objective of this study was the synthesis of racemic AOXD and its geometry has been confirmed by X-ray crystallography. Then, several conditions 
were screened for the diastereoselective synthesis of chiral AOXDs and the relationship between chirality and NMR characteristics was highlighted. As a novel scaffold, the physicochemical properties of AOXD were also investigated. Finally, alchornedine was synthesized, and its spectra and analytical data were compared with those of the isolated compound previously reported. ${ }^{14}$

\section{RESULTS AND DISCUSSION}

As an initial experiment, achiral $\mathrm{N}$-Boc-glycine was used as the starting material for exploring the synthesis of racemic AOXD (Scheme 1). N-Boc-glycine reacted with $N, N$-carbonyl diimidazole (CDI) and N,O-dimethylhydroxylamine to form the corresponding Weinreb amide (2) in $99 \%$ yield. ${ }^{18}$ The nucleophilic addition between 2 and 3,4-dichloro-phenyl magnesium bromide furnished ketone 3 in $86 \%$ yield, which was directly reduced by $\mathrm{NaBH}_{4}$, to yield alcohol 4 in $99 \%$ yield. As a key step in AOXD synthesis, the Mitsunobu reaction between alcohol 4 and $\mathrm{N}$-hydroxyphthalimide (NHPI) was conducted to form the C-ON bond, affording the key intermediate, 5, in 94\% yield. Then, phthaloyl and Boc protections were successively removed by hydrazine hydrate and $\mathrm{HCl}$ treatments, affording 6 and 7 in $94 \%$ and $96 \%$ yield, respectively. Finally, the cyclization reaction of 7 was carried out with $\mathrm{BrCN}$, to afford racemic AOXD 8 and its 4-cyanated side product 9 in $81 \%$ and $17 \%$ yield, respectively (see $\mathrm{SI}$ section I). The presence of such a side product indicated that the nitrogen atom at position $4\left(-\mathrm{HN}-\mathrm{CH}_{2}-\right)$ in $\mathbf{8}$ is more nucleophilic toward $\mathrm{BrCN}$ than those at positions 3 and 2 , respectively. X-ray crystallography confirmed the AOXD structure of 8 (Scheme 1), with a $\mathrm{C}=\mathrm{N}$ double bond located between $\mathrm{N}^{2}$ and $\mathrm{C}^{3}$, rather than $\mathrm{C}^{3}$ and $\mathrm{N}^{4}$, likely because of the stabilization of $p-\pi$ conjugation between the oxygen atom and the $\mathrm{C}=\mathrm{N}$ double bond. Meanwhile, the bivalent character of the oxygen atom induced the expected non-planar geometry of AOXD, in which $\mathrm{C}^{6}$ is located far out of the plane constituted by the $\mathrm{N}^{2}=\mathrm{C}^{3}-\mathrm{N}^{4}$ moiety. Moreover, the $\mathrm{N}^{2}-\mathrm{O}^{1}$ and $\mathrm{N}^{4}-\mathrm{C}^{5}$ bonds are unparallel because of the different bond angles between $\mathrm{N}^{2}$ $\mathrm{O}^{1}-\mathrm{C}^{6}$ and $\mathrm{N}^{4}-\mathrm{C}^{5}-\mathrm{C}^{6}$. Despite the absence of any functional groups at $\mathrm{C}^{5}$ of $\mathrm{AOXD}$, or on ortho position of the phenyl ring, the oxadiazine ring in $\mathbf{8}$ is perpendicular to the phenyl ring, which allows the hydrogen atom $\mathrm{C}^{6} \mathrm{H}$ to be in the same axis as the aromatic ring (for more details of crystallographic data and structure refinement parameters, see SI).

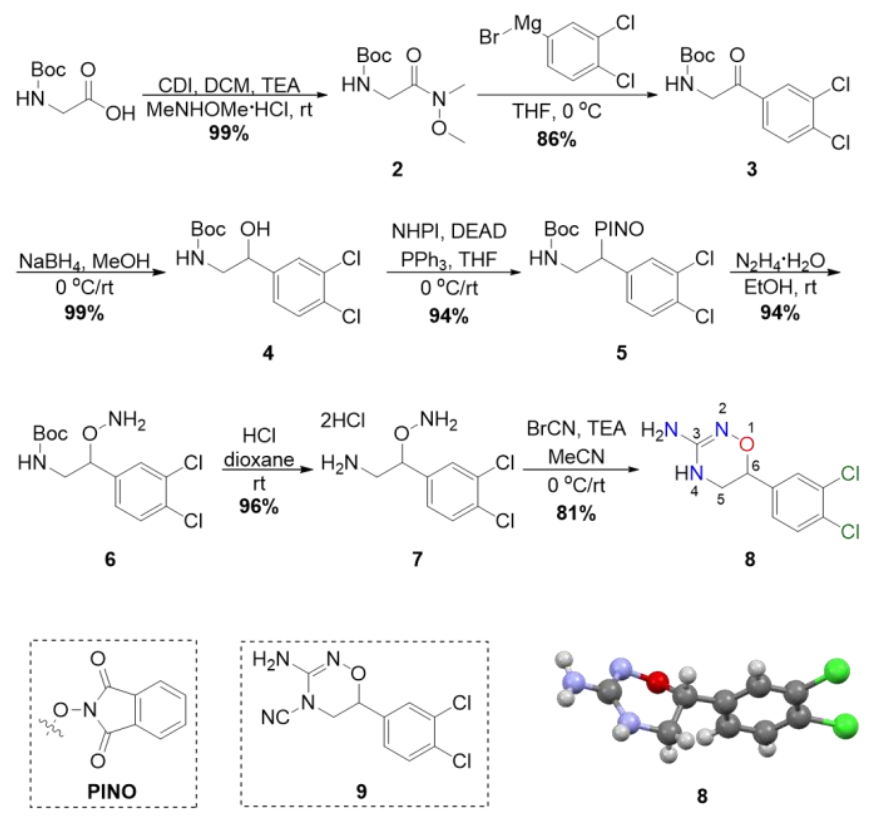

Scheme 1. Synthesis of racemic AOXD 8. X-ray crystallographic structure. Thermal ellipsoids are shown at the $50 \%$ probability level.

After determining the synthesis method of racemic AOXD, we selected $N$-Boc- $L$-alanine, $N$-Boc- $L$-valine and $N$-Boc- $L$-proline as starting materials for the synthesis of chiral AOXDs exhibiting two stereogenic centers (Table 1). Using the synthetic approach described in Scheme 1, the $N$-Boc- $L$-amino acids were transformed to their corresponding ketones through the reactions of their corresponding Weinreb amides with $\mathrm{PhMgBr}$, affording 10, 11 and 12 in $86 \%, 83 \%$ and $83 \%$ overall yield, respectively. To reduce ketones $\mathbf{1 0 - 1 2}$ to their corresponding alcohols, several reductants were evaluated to determine optimal stereoselective conditions allowing one diastereomer to be favored over another (Table 1). Several reduction methods of $\alpha$-amino ketones have been published recently; ${ }^{19-23}$ however none of them showed a systematic comparison of the reduction of $\alpha$-aminoketones by borane- or aluminium-based reducing agents exhibiting more or less bulkiness. 
Table 1. Reduction of ketones 10-12. ${ }^{[a]}$

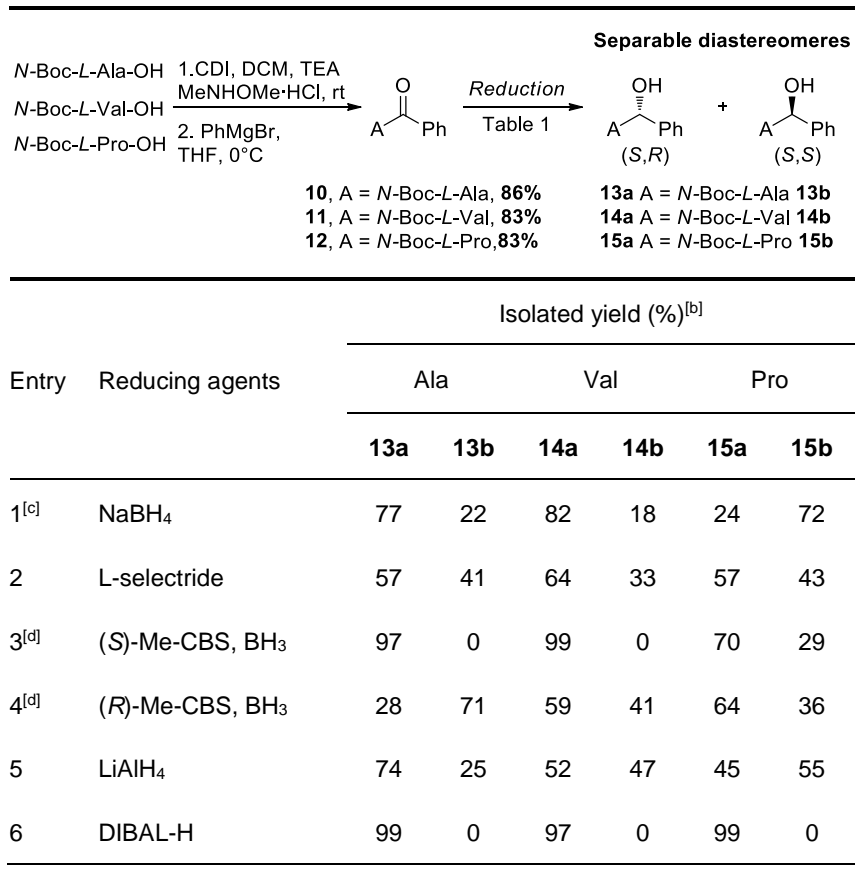

[a] All reactions were carried out with ketones 10,11 or $12(0.1 \mathrm{mmol})$ and the reducing agent $(0.2 \mathrm{mmol})$ in THF $(1 \mathrm{~mL})$ under Ar at $0{ }^{\circ} \mathrm{C}$ for $1 \mathrm{~h}$ and then at $\mathrm{rt}$ for $3 \mathrm{~h}$. Yield of 10, 11, and 12 corresponds to the 2-step overall yield. [b] Isolated yield for each diastereomer identified by comparison with literature ${ }^{38-4}$ [c] THF was replaced with $\mathrm{MeOH}(1 \mathrm{~mL})$. [d] (S)- or (R)-(-)-2-methyl-CBSoxazaborolidine $(0.01 \mathrm{mmol}), \mathrm{BH}_{3}-\mathrm{Me}_{2} \mathrm{~S}$ complex $(0.2 \mathrm{mmol})$ were used.

Partial diastereoselectivity was observed when $\mathrm{NaBH}_{4}$ was used (Table 1, entry 1), privileging formation of the $(S, R)$ diastereomer for Ala- and Val-type ketones $(77 \%(S, R)$ 13a and $22 \%(S, S) \mathbf{1 3 b} ; 82 \%(S, R) \mathbf{1 4 a}$ and $18 \%(S, S) \mathbf{1 4 b}$, respectively) while the $(S, S)$ diastereomer was favored for the Pro-type ketone $(24 \% \quad(S, R) \quad 14 \mathrm{a}$ and $72 \%(S, S) \quad 14 \mathrm{~b})$. The bulky organoborane L-selectride led to a weak diastereoselective reduction of ketones 10-12 (Table 1, entry 2). As a well-known chiral reaction, Corey-Bakshi-Shibata (CBS) reduction was also attempted. ${ }^{24}(S)$-2-Me-CBS yielded only the $(S, R)$ diastereomer in nearly quantitative yield for Ala and Val-type ketones $(97 \%$ 13a; 99\% 14a) (Table 1, entry 3), but appeared less efficient for the Pro-type ketone, leading to diastereomers $(S, R)$ 15a and $(S, S) \mathbf{1 5 b}$ in $70 \%$ and $29 \%$ yield, respectively (Table 1 , entry 3 ). In contrast, (R)-2-Me-CBS led to low diastereoselectivity regardless of the bulkiness of the ketone (Table 1, entry 4). Further, Lithium aluminium hydride $\left(\mathrm{LiAlH}_{4}\right)$ exhibited low diastereoselectivity toward bulky ketones $\mathbf{1 1}$ and 12, favoring the formation of $(S, R)$ 13a (74\% yield) starting from Ala-type ketone 10 (Table 1, entry 5). In contrast to the bulky organoborane Lselectride, the bulky aluminum hydride DIBAL-H diastereoselectively reduced ketones $10-12$, yielding only the single $(S, R)$ diastereomers $\mathbf{1 3} \mathbf{a}-\mathbf{1 5 a}$ in nearly quantitative yield (Table 1, entry 6). This excellent diastereoselectivity of DIBAL-H could be explained by the good complexation between the aluminum atom and the carbonyl oxygen atom as well as the steric hindrance between the isobutyl moieties of DIBAL-H and the Boc group following the Felkin-Anh model (see SI section II).

Next, the Mitsunobu reaction with NHPI was conducted to introduce the $\mathrm{C}-\mathrm{ON}$ bond on the chiral alcohols 13-15 (Figure 2A-D). As expected, key intermediates 16 and 17 were obtained with the inversion of configuration in $74 \%-96 \%$ yield from the corresponding Ala- and Val-type alcohols (Figures 2A and 2B). However, with Pro-type $(S, R)$ alcohol 15a, the Mitsunobu reaction led to the unexpected retention of configuration, affording a key intermediate 18a $(S, R)$ in $94 \%$ yield (Figure $2 C$ ).

Intermediate 18a was first characterized by NMR, and the retention of configuration was confirmed by the $\mathrm{X}$-ray crystallography of AOXD 21, which was obtained from the cyclization of deprotected 18a with BrCN (Figure 2E). Although it is not a frequent case, such configuration retention has been reported wherein the Mitsunobu reaction was performed on sterically hindered alcohols (see SI section III). ${ }^{25}$ Different reactivities were also observed between $(S, R)$ and $(S, S)$ diastereomers 13-15. Moreover, $(S, R)$ alcohols 13a-15a underwent the Mitsunobu reaction at $0{ }^{\circ} \mathrm{C}$ (Figures $2 \mathrm{~A}$ and $2 \mathrm{C}$ ), while a higher temperature ( $\mathrm{rt}$ or $45^{\circ} \mathrm{C}$ ) and an additional equivalent of reagents were required for the reactions involving $(S, S)$ Ala- and Val-type alcohols 13b and 14b (Figure 2B). The Mitsunobu reaction of the $(S, S)$ Pro-type alcohol $15 \mathrm{~b}$ yielded a complex mixture at $45{ }^{\circ} \mathrm{C}$, possibly because of the hindrance of the Boc group under the configuration-retained mechanism (Figure 2D, also see SI section IV).

Finally, after deprotection of the phthaloyl and Boc moieties, key intermediates $\mathbf{1 6 - 1 8}$ were cyclized in the presence of $\mathrm{BrCN}$ to obtain the corresponding diastereomeric AOXDs 19-21 after three steps in 56\%-88\% overall yield. (Figures 2A-C). Interestingly, cyanamide $\mathbf{2 2}$ could be isolated as an intermediate of the cyclization reaction of 18a with $\mathrm{BrCN}$ (Figure 2D, dotted box), indicating that the secondary amine of the pyrroline moiety is more nucleophilic than alkoxyamine toward $\mathrm{BrCN}$ (see $\mathrm{SI}$ section V). The X-ray crystallographic structures of $19 a$ and 21 were obtained as representatives of $(S, S)$ and $(S, R)$ AOXDs (Figure 2E). To facilitate the identification of diastereomeric AOXDs, the ${ }^{1} \mathrm{H}$ chemical shifts $(\delta)$ and coupling constants $(\mathcal{J})$ of 19-21 in DMSO- $d^{6}$ were determined and significant differences were observed. In particular, the proton of the $>\mathrm{CH}^{\prime}-\mathrm{O}-$ moiety in $(S, S)$ 19a and 20a was detected at 3.82-4.09 ppm, with a coupling constant $\left(\mathrm{J}_{\mathrm{H}^{\prime}}\right)$ of $8.2-8.5 \mathrm{~Hz}$ (Figure $2 \mathrm{~F}$ ). In contrast, the corresponding proton in $(S, R) \mathbf{1 9 b}, \mathbf{2 0 b}$ and $\mathbf{2 1}$ was observed at 4.55-4.98 ppm, with $J_{H^{\prime}}$ of about $3-4.3 \mathrm{~Hz}$.

The AOXDs described herein have not been previously characterized in terms of physicochemical properties. The presence of an oxygen atom in the a-position of the guanidine moiety would likely affect $p K_{a}$ as well as the distribution coefficient log D. These parameters were experimentally measured and compared with those of the cyclic guanidine analogs 23-25 (Figure 3). Because of the strong basicity of guanidine, the $\mathrm{p} K_{\mathrm{a}}$ of $\mathbf{2 3}$ was too high to be measured under the titration condition and was estimated to be $>13$. A negative value of $\log D\left(D_{7.4}=-0.64 \pm 0.06\right)$ indicates that 23 is hydrophilic and unfavorable for membrane permeability by passive diffusion. Furthermore, the introduction of one double bond in $\mathbf{2 3}$ resulted in the formation of unsaturated cyclic guanidine 24. As expected from the conjugation between the benzene ring and the the guanidine moiety, $p K_{\mathrm{a}}$ decreased to 11.37 and $\log \mathrm{D}_{7.4}$ increased to $1.90 \pm 0.04$. Such a strong increase in log $D$ is because of the decrease in $\mathrm{pKa}$, and the presence of both chlorine atoms on the aromatic ring. Next, the unsaturated carbon atom adjacent to the guanidine moiety in $\mathbf{2 4}$ was replaced by a nitrogen atom, leading to the formation of cyclic iminoguanidine 25 . The resulting $\mathrm{p} K_{\mathrm{a}}$ dropped to 10.02 and $\log D_{7.4}$ slightly decreased to $1.70 \pm 0.03$, indicating sufficient hydrophobicity 
(A)

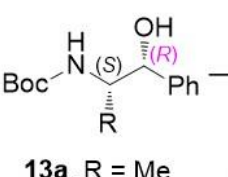

14a, $\mathrm{R}=i-\mathrm{Pr}$ inversion of config.

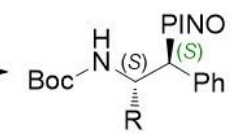

16a, $R=M e, 89 \%$

$17 \mathrm{a}, \mathrm{R}=i-\operatorname{Pr}, 81 \%$
1. $\mathrm{N}_{2} \mathrm{H}_{4} \cdot \mathrm{H}_{2} \mathrm{O}$ 2. $\mathrm{HCl}$ 3. $\mathrm{BrCN}, \mathrm{TEA}$<smiles>[R]C1NC(N)=NO[C@@H]1c1ccccc1</smiles>

19a, $R=M e, 65 \%$

20a, $\mathrm{R}=i-\operatorname{Pr}, 70 \%$
(E)

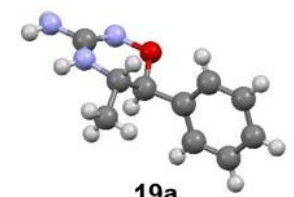

$19 a$

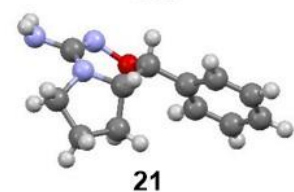

(F)

$19 b, R=M e, 66 \%$

$16 \mathrm{~b}, \mathrm{R}=\mathrm{Me}, 96 \%$
$17 \mathrm{~b}, \mathrm{R}=i-\operatorname{Pr}, 74 \%$

1. $\mathrm{N}_{2} \mathrm{H}_{4} \cdot \mathrm{H}_{2} \mathrm{O}$
$\underset{\text { 3. } \mathrm{BCl}}{\text { 3rCN, TEA }}$
20b, $\mathrm{R}=i-\operatorname{Pr}, 56 \%$
$\mathrm{Y}^{\mathrm{N}}$
S)

THF, it or $45^{\circ} \mathrm{C}$

14b, $\mathrm{R}=i-\mathrm{Pr}$

inversion of config.

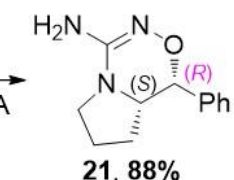

1. $\mathrm{N}_{2} \mathrm{H}_{4} \cdot \mathrm{H}_{2} \mathrm{O}$
$\underset{\text { 3. } \mathrm{BCl}}{\text { 3rCN, TEA }}$

$21,88 \%$

$15 a$

retention of config.

$18 a, 94 \%$

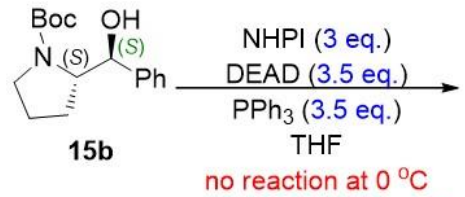

Boc PINO

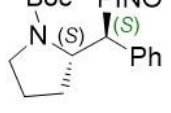

$18 b, 0 \%$

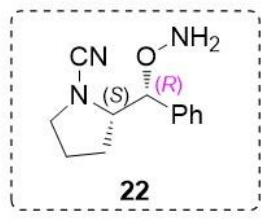

$$
\text { 19a, 20a }
$$

$(S, S): \delta_{\mathrm{H}^{\prime}} 3.82 \sim 4.09 \mathrm{ppm}$ $J_{\mathrm{H}^{\prime}} 8.2 \sim 8.5 \mathrm{~Hz}$

$$
\mathrm{R}^{1} \mathrm{R}_{19} \mathrm{R}^{2}, 20 \mathrm{~b}, 21
$$

$(S, R): \delta_{\mathrm{H}^{\prime}} 4.55 \sim 4.98 \mathrm{ppm}$ $J_{H^{\prime}} 3.0 \sim 4.3 \mathrm{~Hz}$

Figure 2. (A-D) Mitsunobu reaction and cyclization to afford AOXDs 19a-b, 20a-b, 21. Yields for 19a, 19b, 20a, 20b, and 21 correspond to the three-step overall yield. (E) X-ray crystallographic structures of $19 \mathrm{a}$ and $\mathbf{2 1}$. Thermal ellipsoids are shown at the $50 \%$ probability level. ( $\mathrm{F}$ ) Ranges of ${ }^{1} \mathrm{H}$ chemical shift and coupling constant of diastereomeric AOXDs 19-21 in DMSO- $d^{6}$. 
that can be attributed to the transposition of the $\alpha$-nitrogen atom in 25 by an oxygen atom, dramatically decreasing $p K_{\mathrm{a}}$ to 6.91 with a suitable $\log D_{7.4}$ at $1.88 \pm 0.06$. Diastereomers $20 \mathrm{~b}$ and $\mathbf{2 1}$ were slightly more basic and showed pKa values of 7.14 and 7.44, respectively. Distribution coefficient $\log D_{7.4}$ of $\mathbf{8}, \mathbf{2 0 b}$, and 21 was $<2$ despite the presence of the substituents. This is a promising phenomenon as it allows a comfortable margin of maneuver compared to the Lipinski recommendations. ${ }^{26}$ Compared to non-conjugated cyclic guanidine 23, AOXD 8, 20b and $\mathbf{2 1}$ are more than six orders of magnitude less basic. Interestingly, at the physiological $\mathrm{pH} 7.4$, a significant proportion of AOXDs are not protonated, improving their ability to cross biological barriers, unlike compounds 23-25 that only exist in their protonated forms at physiological $\mathrm{pH}$. Finally, we determined the metabolic stability of AOXDs $8,20 \mathrm{~b}$, and 21 in the presence of mouse liver microsomes (MLM), and all of them exhibited complete stability after $1 \mathrm{~h}$. For comparison, testorenone and dextrometorphan, FDA-approved drugs used as positive controls in this assay, showed half-lives of 5 and 19 min, respectively. These distinctive physicochemical properties and its stability in aqueous biological media make AOXD a promising scaffold for drug development.

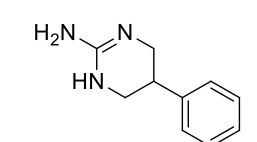

23

$\mathrm{p} K_{\mathrm{a}}>13$

$\log D_{7.4}=-0.64+/-0.06$

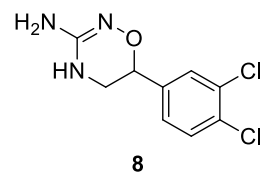

$\mathrm{p} K_{\mathrm{a}}=6.91+/-0.06$

$\log D_{7.4}=1.88+/-0.06$

$\mathrm{t}_{1 / 2}$ (MLM): stable after $1 \mathrm{~h}$

MLM : Mouse Liver Microsomes

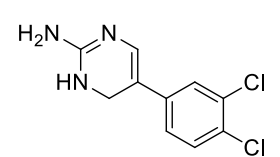

24

$\mathrm{p} K_{\mathrm{a}}=11.37+/-0.01$

$\log D_{7.4}=1.90+/-0.04$

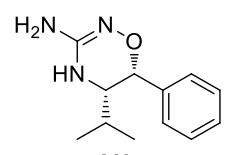

20b

$\mathrm{p} K_{\mathrm{a}}=7.14+/-0.05$

$\log D_{7.4}=1.64+/-0.07$

$\log D_{7.4}=0.86+/-0.03$
$t_{1 / 2}$ (MLM): stable after $1 \mathrm{~h}$

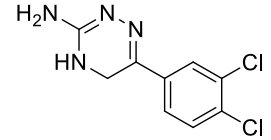

25

$\mathrm{p} K_{\mathrm{a}}=10.02+/-0.05$

$\log D_{7.4}=1.70+/-0.03$

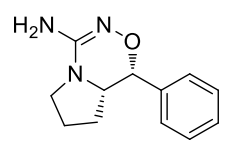

21

(MLM): stable after $1 \mathrm{~h} \quad \mathrm{t}_{1 / 2}$ (MLM): stable after $1 \mathrm{~h}$ the nitrogen atom at position 2 was protected in the presence of $(\mathrm{Boc})_{2} \mathrm{O}$, affording 34 in $91 \%$ yield (Scheme 2 ). The position of the Boc group was characterized unambiguously in 2D NMR (see SI section VIII). The amino group in 34 was then deprotonated by $\mathrm{NaH}$ and alkylated by prenyl bromide in $\mathrm{THF}$, producing 35 in $76 \%$ yield. After Boc deprotection by $\mathrm{HCl}$ in dioxane, the structure of alchornedine 1, as proposed by Barrosa et al., ${ }^{14}$ was obtained in $96 \%$ yield. Full structural characterization of $\mathbf{1}$ is shown in SI section $\mathrm{IX}$, including ${ }^{1} \mathrm{H}$ and ${ }^{13} \mathrm{C}$ NMR, 2D-NMRs, and HRMS.

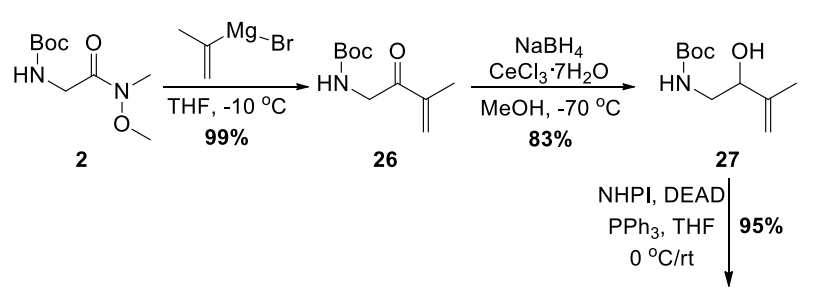

$2 \mathrm{HCl}$

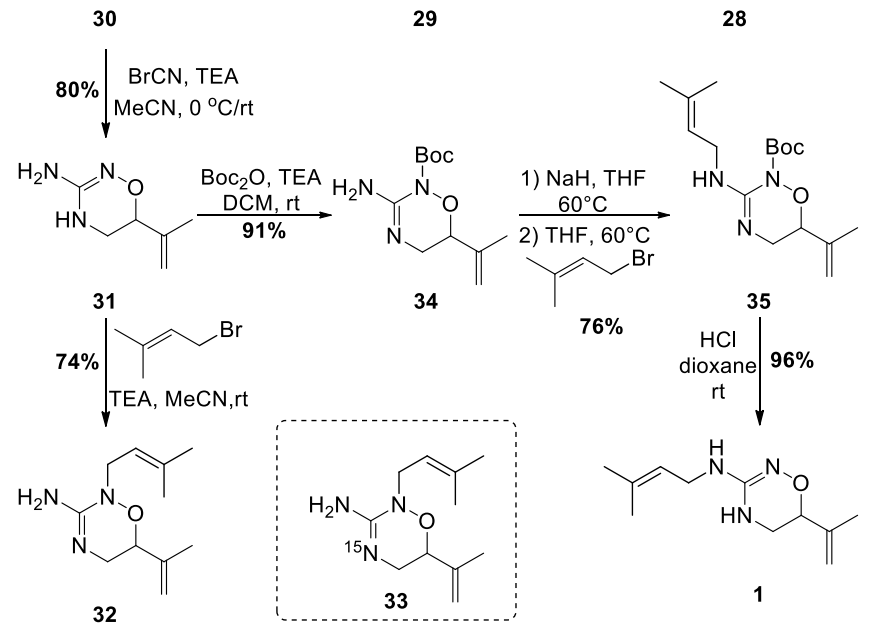

Scheme 2. Synthesis of of alchornedine 1.

Figure 3. $p K_{a}, \log D_{7.4}$, and hepatic stability in mouse liver microsomes of AOXDs and its bioisosteres.

Furthermore, the proposed synthetic approach for AOXD was utilized toward the total synthesis of alchornedine, the only natural product exhibiting a 3-amino-1,2,4-oxadiazine (AOXD) scaffold. Starting from $N$-Boc-glycine, AOXD 31 was synthesized as described previously (Scheme 2), except for the reduction of $\alpha, \beta$-unsaturated ketone 26, which was performed with $\mathrm{NaBH}_{4}$ in the presence of $\mathrm{CeCl}_{3}$. AOXD 31 was obtained from 2 after six steps and $61 \%$ overall yield. Direct alkylation of $\mathbf{3 1}$ using prenyl bromide in the presence of TEA afforded 32 in $74 \%$ yield (Scheme 2). To confirm the position of the prenyl moiety, we synthesized its ${ }^{15} \mathrm{~N}$-labeled analog (33) based on the principle that NMR signals of hydrogen or carbon atoms directly linked to ${ }^{15} \mathrm{~N}$ will split. Following the synthetic method shown in Scheme 2 33 was obtained after eight steps and $40 \%$ overall yield starting from ${ }^{15} \mathrm{~N}$-Boc-glycine (see SI section $\mathrm{VI}$ ). The position of the prenyl moiety in 33 could be easily identified in the ${ }^{1} \mathrm{H}$ NMR spectra based on the presence of the $-\mathrm{NH}_{2}$ signal as well as the split of ${ }^{13} \mathrm{C}$ signals of $>\mathrm{C}={ }^{15} \mathrm{~N}$ - and $={ }^{15} \mathrm{~N}-\mathrm{CH}_{2}-$, while no split was observed for $>\mathrm{N}-\mathrm{CH}_{2}-$ from the prenyl moiety (see $\mathrm{SI}$ section VII). To modify the reactivity of $\mathbf{3 1}$ towards electrophiles,
To confirm the structure of alchornedine, NMR spectra of 1 were compared with those reported for alchornedine (Figure 4A, SI section X). ${ }^{14}$ Significant differences were found in both chemical shifts and coupling constants suggesting that Barrosa's proposed structure for alchornedine was incorrect. Such an error could be explained by the fact that all NMRs analyses by Barrosa et al. were performed in MeOD, which prevented the observation of all signals corresponding to $\mathrm{NH}$, which are the only protons between the prenyl group and $\mathrm{CH}_{2}$ at position 5 of the 1,2,4-oxadiazine scaffold.

The reported mass spectrum of alchornedine shows a molecular peak at $210.16(\mathrm{M}+\mathrm{H})$, as well as a peak of fragmentation at 194.16, corresponding to the loss of a hydroxyl moiety. This result is not consistent with the 3-amino-1,2,4oxadiazine scaffold, but rather with that of the imidazolidine-1-ol scaffold shown in Figure 4B. Moreover, the NOESY signal reported for alchornedine between $\mathrm{CH}_{2}$ in the ring and $\mathrm{CH}_{2}$ of the prenyl moiety is attributed to the presence of the imidazolidine-1-ol scaffold. Furthermore, this imidazolidin-1-ol scaffold is identical to the reported structures of natural products, as it is found in alkaloids such as alchornein and isoalchornein. ${ }^{42}$ Finally, it can be noticed that both the alkaloids correspond to a 
cyclized form of the structure we propose for alchornedine. However, the synthesis of this structure (Fig 4B) is not trivial and is under progress in our laboratory to confirm our hypothesis.

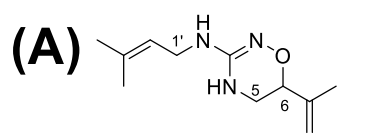

$\begin{gathered}\text { Synthesized alchornedine } \\ \text { (this work) }\end{gathered}$
$N M R$ in MeOD.

NMR in $\underline{\mathrm{MeOD}}$

$\delta\left(\mathrm{H}^{1}\right): 3.54(\mathrm{~d}, J=6.8 \mathrm{~Hz}, 2 \mathrm{H})$ $\delta\left(\mathrm{H}^{5}\right): 3.25(\mathrm{dd}, J=11.2,9.6 \mathrm{~Hz}, 1 \mathrm{H})$ $3.40(\mathrm{dd}, J=11.2,3.3 \mathrm{~Hz}, 1 \mathrm{H})$ No NOESY Correlation between $\mathrm{H}^{5}$ and $\mathrm{H}^{1}$ $\underline{M S}: \mathrm{m} / \mathrm{z}=210,16$

(B)

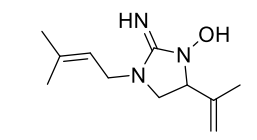

Hypothesis for the structure of alchornedine $\delta\left(\mathrm{H}^{6}\right): 3.97(\mathrm{dd}, J=9.6,3.3 \mathrm{~Hz}, 1 \mathrm{H})$ proposed structure of lchornedine 1 by Barrosa and total synthesized by our group
Isoalchorneine
Figure 4. (A) Analytical comparison between synthesized and isolated alchornedine. (B) Alternative structure for alchornedine. (C) Structures of natural products Alchorneine and Isoalchorneine.

\section{Conclusions}

A general method for the synthesis of 3-amino-1,2,4oxadiazine (AOXD) scaffold was developed by using commercially available $\mathrm{N}$-Boc amino acids as starting materials. We developed diastereoselective reactions to synthesize chiral compounds exhibiting non-planar geometries and promising physicochemical properties, because of which the compounds could be applicable in medicinal chemistry approaches. Based on the established method, alchornedine was synthesized and its structure was determined; however, spectral inconsistences between the synthesized alchornedine and the one isolated from the leaves of Alchornea glandulosa indicated that the proposed structure of alchornedine is incorrect. The total synthesis of alternative structures of alchornedine is currently underway. The determination of the correct structure of alchornedine will benefit medicinal chemistry, because alchornedine exhibits promising antiprotozoal activity against American trypanosomiasis. ${ }^{14}$

\section{EXPERIMENTAL SECTION}

\section{General information and typical procedures}

All commercial reagents were used without additional purification. Analytical TLC was performed using silica gel plates Merck $60 \mathrm{~F}_{254}$ and plates were visualized by exposure to ultraviolet light $(254 \mathrm{~nm})$. Compounds were purified on silica gel Merck 60 (particle size 0.040-0.063 nm). ${ }^{1} \mathrm{H},{ }^{13} \mathrm{C}$ and ${ }^{15} \mathrm{~N}$ NMR spectra were recorded on Bruker Avance Spectrometer operating at $400 \mathrm{MHz}, 101 \mathrm{MHz}$ and $51 \mathrm{MHz}$, respectively. Structural assignments were made with additional information from gCOSY, gHSQC, and gHMBC experiments. All chemical shift values $\delta$ and coupling constants $J$ are quoted in ppm and in $\mathrm{Hz}$, respectively, multiplicity $(\mathrm{s}=$ singulet, $\mathrm{d}=$ doublet, $\mathrm{t}=$ triplet, $\mathrm{q}=$ quartet, $\mathrm{m}=$ multiplet, $\mathrm{br}=$ broad). Analytical RP-HPLC-MS was performed using a LC 1200 Agilent with quadrupole-time-offlight (QTOF) (Agilent Accurate Mass QToF 6520) with a Zorbax Agilent C18-column $(\mathrm{C} 18,50 \mathrm{~mm} \times 2.1 \mathrm{~mm} ; 1.8 \mu \mathrm{m})$ using the following parameters: 1$)$ The solvent system: $A(0.05 \%$ of formic acid in acetonitrile) and $B\left(0.05 \%\right.$ of formic acid in $\left.\mathrm{H}_{2} \mathrm{O}\right)$; 2) $A$ linear gradient: $t=0 \mathrm{~min}, 98 \% \mathrm{~B} ; \mathrm{t}=8 \mathrm{~min}, 0 \% \mathrm{~B} ; \mathrm{t}=12.5 \mathrm{~min}$, $0 \% \mathrm{~B} ; \mathrm{t}=12.6 \mathrm{~min}, 98 \% \mathrm{~B} ; \mathrm{t}=13 \mathrm{~min}, 98 \% \mathrm{~B} ; 3$ ) Flow rate of $0.5 \mathrm{~mL} / \mathrm{min}$; 4) Column temperature: $35{ }^{\circ} \mathrm{C}$; 5) DAD scan from $190 \mathrm{~nm}$ to $700 \mathrm{~nm}$; 6) lonization mode : $\mathrm{ESI}^{+}$or ESI. HPLC were performed using a Dionex UltiMate 3000 using the following parameters: Flow rate of $0.5 \mathrm{~mL} / \mathrm{min}$, column temperature: $30^{\circ} \mathrm{C}$, solvent system: $A(\mathrm{MeOH})$ and $B\left(0.05 \%\right.$ of TFA in $\left.\mathrm{H}_{2} \mathrm{O}\right), t=0$ $\min$ to $1 \mathrm{~min}$ : 50 to $60 \%$ of $B$, then $t=1 \mathrm{~min}$ to $t=10 \mathrm{~min}: 60$ to $100 \%$ of $B$ and $t=10 \mathrm{~min}$ to $t=15 \mathrm{~min}: 100 \%$ of $B$. The singlecrystal structure analysis was performed using $X$-ray diffraction with a Thermo Fisher ESCALAB 250 diffractometer.

Compound 23 - 25 were prepared according to previous reported literatures. ${ }^{27-30}$

1. Typical procedure 1 (TP1) for the preparation of Weinreb amides 2, 36 - 38 and 45

CDI (1.5 eq.) was added slowly to a solution of $\mathrm{N}$-Boc-amino acid (1 eq.) in DCM and stirred at rt for 30 minutes until $\mathrm{CO}_{2}$ evolution ceased. Then, TEA (1.5 eq.) was added dropwise to the reaction mixture followed by the addition of $\mathrm{N}, \mathrm{O}$ dimethylhydroxylamine hydrochloride (1.5 eq.). After the addition was complete, the resulting mixture was stirred at $\mathrm{rt}$ for an additional $16 \mathrm{~h}$. The reaction was then quenched by addition of water and the resulting solution was extracted with DCM thrice. The combined organic phases were washed with brine, dried over anhydrous $\mathrm{Na}_{2} \mathrm{SO}_{4}$ and filtered. The filtrate was concentrated in vacuo without further purification to afford the desired Weinreb amide.

2. Typical procedure 2 (TP2) for the preparation of ketones 3,10 - 12, 26 and 46

Grignard reagent $(1.5 \sim 3.5$ eq. $)$ in THF was added dropwise to a solution of Weinreb amide (1 eq.) in THF at $0^{\circ} \mathrm{C}$ under $\mathrm{Ar}$. After the addition was complete, the reaction mixture was stirred at $0{ }^{\circ} \mathrm{C}$ overnight. The reaction mixture was then poured slowly into saturated $\mathrm{NH}_{4} \mathrm{Cl}$ aqueous solution at $0{ }^{\circ} \mathrm{C}$. After stirring for an additional $10 \mathrm{~min}$, the resulting mixture was extracted with EtOAc thrice. The combined organic phases were washed with brine, dried over anhydrous $\mathrm{Na}_{2} \mathrm{SO}_{4}$ and filtered. The filtrate was concentrated in vacuo and purified by silica gel column chromatography to afford the desired ketone.

3. Typical procedure 3 (TP3) for the preparation of alcohols 4 , $13-15,27$ and 47

Method 1 associate with the use of $\mathrm{NaBH}_{4}$ :

$\mathrm{NaBH}_{4}$ (4 eq.) was added portionwise to a solution of ketone (1 eq.) in $\mathrm{MeOH}$ at $0^{\circ} \mathrm{C}$ and the resulting mixture was stirred at $\mathrm{rt}$ for an additional $6 \mathrm{~h}$. The mixture was then poured slowly into a chilled saturated $\mathrm{NH}_{4} \mathrm{Cl}$ aqueous solution, stirred for an additional $10 \mathrm{~min}$. The resulting mixture was concentrated in vacuo to remove $\mathrm{MeOH}$ and then extracted with EtOAc thrice. The combined organic phases were washed with brine, dried over anhydrous $\mathrm{Na}_{2} \mathrm{SO}_{4}$ and filtered. The filtrate was concentrated in vacuo and purified by silica gel column chromatography or reverse phase $\mathrm{C} 18$ column chromatography to afford the desired alcohol.

Method 2 associate with the use of DIBAL-H:

DIBAL-H (1 M in THF, 2 eq.) was added dropwise to a solution of ketone (1 eq.) in dry THF maintained at $0^{\circ} \mathrm{C}$ under $\mathrm{Ar}$ and the reaction was stirred at $\mathrm{rt}$ for $6 \mathrm{~h}$. The reaction mixture was then poured slowly into a chilled saturated $\mathrm{NH}_{4} \mathrm{Cl}$ aqueous solution, stirred for an additional $10 \mathrm{~min}$ and then extracted with EtOAc thrice. The combined organic phases were washed with brine, dried over anhydrous $\mathrm{Na}_{2} \mathrm{SO}_{4}$ and filtered. The filtrate was 
concentrated in vacuo without further purification to afford the desired alcohol.

Method 3 associate with the use of $(R)-2$-Me-CBS and borane dimethylsulfide complex:

Borane dimethylsulfide complex (2 eq.) was added dropwise to a solution of $(R)$-2-Me-CBS-oxazaborolidine $(0.4 \mathrm{M}$ in THF, 0.1 eq.) in $\mathrm{THF}$ at $0{ }^{\circ} \mathrm{C}$ under $\mathrm{Ar}$ and the resulting solution was stirred for $20 \mathrm{~min}$. The ketone solution (1 eq) in THF was added slowly at $0^{\circ} \mathrm{C}$ to the borane solution over a period of $15 \mathrm{~min}$, the ice bath was removed, and the resulting mixture was stirred at it for $16 \mathrm{~h}$. The reaction solution was poured slowly into a chilled saturated citric acid aqueous solution $(30 \mathrm{~mL})$. After stirring for an additional $10 \mathrm{~min}$, the resulting mixture was extracted with EtOAc thrice. The combined organic phases were concentrated in vacuo and purified by reverse phase C18 column chromatography to afford the desired alcohol.

Method 4 associate with the use of $\mathrm{LiAlH}_{4}$ :

A solution of ketone (1 eq.) in dry THF was added dropwise to a suspension of $\mathrm{LiAlH}_{4}$ (2 eq.) in $\mathrm{THF}$ at $0^{\circ} \mathrm{C}$ under $\mathrm{Ar}$ and then stirred at rt for $6 \mathrm{~h}$. The reaction mixture was poured slowly into a chilled saturated $\mathrm{NH}_{4} \mathrm{Cl}$ aqueous solution, and stirred for an additional $10 \mathrm{~min}$ while the temperature was kept at $0^{\circ} \mathrm{C}$. The resulting mixture was then extracted with EtOAc thrice. The combined organic phases were washed with brine, dried over anhydrous $\mathrm{Na}_{2} \mathrm{SO}_{4}$ and filtered. The filtrate was concentrated in vacuo and purified by silica gel column chromatography to afford the desired alcohol.

Method 5 associate with the use of $\mathrm{NaBH}_{4}$ and $\mathrm{CeCl}_{3}$ :

Trichlorocerium heptahydrate (1.6 eq.) was added to a solution of ketone (1 eq.) in $\mathrm{MeOH}$ and sonicated until the suspension became clear. Then, the mixture was cooled to $-70{ }^{\circ} \mathrm{C}, \mathrm{NaBH}_{4}$ (1.5 eq.) was added portionwise and the reaction mixture was stirred at $-70^{\circ} \mathrm{C}$ for an additional $1 \mathrm{~h}$. The reaction mixture was allowed to warmed-up to $-20^{\circ} \mathrm{C}$ and then quenched carefully by the addition of chilled $\mathrm{H}_{2} \mathrm{O}$. The crude was concentrated in vacuo to remove $\mathrm{MeOH}$ and the aqueous suspension was extracted with EtOAc thrice. The combined organic phases were washed with brine, dried over anhydrous $\mathrm{Na}_{2} \mathrm{SO}_{4}$ and filtered. The filtrate was concentrated in vacuo and purified by silica gel column chromatography to afford the desired alcohol.

4. Typical procedure 4 (TP4) for the preparation of the PINO derivatives $5,16-18,28$ and 48

The solution of corresponding alcohol $4,13-15$ or 27 (1 eq), NHPI $\left(1.5 \sim 3\right.$ eq) and $\mathrm{PPh}_{3}(1.8 \sim 3.5$ eq. $)$ in dry THF was cooled $0{ }^{\circ} \mathrm{C}$, degassed and backfilled with Ar thrice. Then, $\operatorname{DEAD}\left(1.8 \sim 3.5\right.$ eq.) was added dropwise at $0{ }^{\circ} \mathrm{C}$ under $\mathrm{Ar}$ and allowed to stir at the given temperature for $16 \mathrm{~h}$. The reaction mixture was quenched by the addition of water and extracted with EtOAc thrice. The combined organic phases were washed with brine, dried over anhydrous $\mathrm{Na}_{2} \mathrm{SO}_{4}$ and filtered. The filtrate was concentrated in vacuo and purified by silica gel column chromatography to afford the desired product.

5. Typical procedure 5 (TP5) for the preparation of compounds 6 , 29, 39, 41, 43 and 49

Hydrazine hydrate (15 eq.) was added dropwise to a solution of $\mathrm{N}$-alkoxyl phthalimide (1 eq.) in $\mathrm{EtOH}$ and stirred at $\mathrm{rt}$ for $5 \mathrm{~h}$. The reaction mixture was concentrated in vacuo and purified by silica gel column chromatography to afford the desired product.

6. Typical procedure 6 (TP6) for the preparation of compounds 7 , 30, 40, 42, 44 and 50

Boc amino alkoxyamine (1 eq.) was added to a hydrogen chloride solution in dioxane $(4 \mathrm{M})$ and stirred at rt for $16 \mathrm{~h}$. The reaction was concentrated in vacuo and dried under reduced pressure overnight to afford the alkoxyamines as a dihydrochloride salt.

7. Typical procedure 7 (TP7) for the preparation of AOXDs 8, 19 $-21,31$ and 51

TEA (4 eq.) was added dropwise to a solution of amino alkoxyamine dihydrochloride (1 eq.) in dry $\mathrm{MeCN}$ at $0{ }^{\circ} \mathrm{C}$, under argon and the mixture was stirred for $5 \mathrm{~min}$. Then a solution of $\mathrm{BrCN}$ (1.1 eq.) in MeCN was added dropwise and stirring was maintained for $30 \mathrm{~min}$ at $0^{\circ} \mathrm{C}$. The ice bath was removed and the reaction stirred for $16 \mathrm{~h}$ while warming to ambient temperature. The crude was concentrated in vacuo and purified by reverse phase $\mathrm{C} 18$ column chromatography $\left(\mathrm{MeCN} / \mathrm{H}_{2} \mathrm{O}\right)$ to afford the desired AOXD.

$\mathrm{N}$-(3-methylbut-2-en-1-yl)-6-(prop-1-en-2-yl)-5,6-dihydro-4H1,2,4-oxadiazin-3-amine (1). Tert-butyl 3-((3-methylbut-2-en-1yl)amino)-6-(prop-1-en-2-yl)-5,6-dihydro-2H-1,2,4-oxadiazine-2carboxylate 35 (1 eq., $6.5 \mathrm{mg}, 0.021 \mathrm{mmol}$ ) was added to a solution of $\mathrm{HCl}$ in dioxane $(4 \mathrm{M}, 1 \mathrm{~mL})$ and stirred at $\mathrm{rt}$ for $16 \mathrm{~h}$. The reaction mixture was concentrated in vacuo and basified with a saturated aqueous solution of $\mathrm{NaHCO}_{3}$ until pH reached 8 . The crude was concentrated in vacuo and directly purified by reverse phase $\mathrm{C} 18$ column chromatography $\left(\mathrm{MeCN} / \mathrm{H}_{2} \mathrm{O}\right)$ to afford compound 1 as a white solid $(4.2 \mathrm{mg}, 96 \%)$. ${ }^{1} \mathrm{H}$ NMR (400 $\left.\mathrm{MHz}, \mathrm{DMSO}-d^{6}\right)$ : $\delta 5.76$ (s, 1H), 5.20 (t, $J=6.9 \mathrm{~Hz}, 1 \mathrm{H}$ ), 4.95 (s, $1 \mathrm{H}), 4.89(\mathrm{~s}, 1 \mathrm{H}), 4.63-4.57(\mathrm{~m}, 1 \mathrm{H}), 3.72(\mathrm{dd}, J=9.5,3.1 \mathrm{~Hz}$, $1 \mathrm{H}), 3.43-3.36(\mathrm{~m}, 2 \mathrm{H}), 3.28-3.24(\mathrm{~m}, 1 \mathrm{H}), 3.01(\mathrm{t}, J=10.3$ $\mathrm{Hz}, 1 \mathrm{H}), 1.70(\mathrm{~s}, 3 \mathrm{H}), 1.66(\mathrm{~s}, 3 \mathrm{H}), 1.59(\mathrm{~s}, 3 \mathrm{H}) .{ }^{13} \mathrm{C}\left\{{ }^{1} \mathrm{H}\right\} \mathrm{NMR}$ (101 MHz, DMSO-d6): $\delta$ 153.8, 142.5, 132.6, 122.8, 111.9, 74.5, 43.7, 38.8, 25.4, 19.0, 17.7. ${ }^{1} \mathrm{H}$ NMR $\left(400 \mathrm{MHz}, \mathrm{MeOD}-d^{4}\right): \delta$ $5.29-5.20(\mathrm{~m}, 1 \mathrm{H}), 5.02(\mathrm{q}, J=1.2 \mathrm{~Hz}, 1 \mathrm{H}), 5.01-4.95(\mathrm{~m}$, $1 \mathrm{H}), 3.97$ (dd, $J=9.6,3.3 \mathrm{~Hz}, 1 \mathrm{H}$ ), $3.54(\mathrm{~d}, J=6.8 \mathrm{~Hz}, 2 \mathrm{H}), 3.40$ (dd, $J=11.2,3.3 \mathrm{~Hz}, 1 \mathrm{H}$ ), 3.25 (dd, $J=11.2,9.6 \mathrm{~Hz}, 2 \mathrm{H}), 1.79$ (t, $J=1.1 \mathrm{~Hz}, 3 \mathrm{H}), 1.73(\mathrm{~d}, J=1.4 \mathrm{~Hz}, 3 \mathrm{H}), 1.67(\mathrm{~d}, J=1.3 \mathrm{~Hz}, 3 \mathrm{H})$. HRMS (ESI): $\mathrm{m} / \mathrm{z}$ calcd. for $\mathrm{C}_{11} \mathrm{H}_{20} \mathrm{~N}_{3} \mathrm{O}[\mathrm{M}+\mathrm{H}]^{+}:$210.1606, found: 210.1610 .

Tert-butyl (2-(methoxy(methyl)amino)-2-oxoethyl)carbamate (2). Following general procedure TP1 and starting from $\mathrm{N}$-Boc glycine ( 1 eq., $4 \mathrm{~g}, 22.8 \mathrm{mmol}$ ), CDI (1.5 eq., $5.55 \mathrm{~g}, 34.2 \mathrm{mmol}$ ), TEA (1.5 eq, $4.76 \mathrm{~mL}, \quad 34.2 \mathrm{mmol})$ and $\mathrm{N}, \mathrm{O}$ dimethylhydroxylamine hydrochloride (1.5 eq., $3.34 \mathrm{~g}, 34.2$ $\mathrm{mmol})$ in DCM $(50 \mathrm{~mL})$, the title compound 2 was obtained as a white solid (4.94 g, 99\%). ${ }^{1} \mathrm{H} \mathrm{NMR}\left(400 \mathrm{MHz}, \mathrm{CDCl}_{3}\right): \delta 5.26$ (s, $1 \mathrm{H}), 4.07$ (d, $J=3.8 \mathrm{~Hz}, 2 \mathrm{H}), 3.70(\mathrm{~s}, 3 \mathrm{H}), 3.19$ (s, 3H), 1.45 (s, $9 \mathrm{H}$ ). The analytical data are consistent with the previously reported characterization. ${ }^{31}$

Tert-butyl (2-(3,4-dichlorophenyl)-2-oxoethyl)carbamate (3). According to general procedure TP2, 3,4-dichloro-phenyl magnesium bromide ( 1.5 eq., $0.5 \mathrm{M}, 27.5 \mathrm{~mL}, 13.7 \mathrm{mmol}$ ) was reacted with 2 (1 eq., $2 \mathrm{~g}, 9.2 \mathrm{mmol}$ ) in THF $(10 \mathrm{~mL})$. After workup, the crude was purified by silica gel column chromatography (heptane:EtOAc $=5: 1$ ) to afford 3 as a white solid $(2.4 \mathrm{~g}, 86 \%$ ) ${ }^{1} \mathrm{H} \mathrm{NMR}\left(400 \mathrm{MHz}, \mathrm{CDCl}_{3}\right): \delta 8.04(\mathrm{~d}, J=2.1 \mathrm{~Hz}, 1 \mathrm{H}), 7.76(\mathrm{dd}$, $J=8.4,2.1 \mathrm{~Hz}, 1 \mathrm{H}), 7.58(\mathrm{~d}, J=8.3 \mathrm{~Hz}, 1 \mathrm{H}), 5.45(\mathrm{~s}, 1 \mathrm{H}), 4.60$ $(\mathrm{d}, J=4.7 \mathrm{~Hz}, 2 \mathrm{H}), 1.47(\mathrm{~s}, 9 \mathrm{H})$. The analytical data are consistent with the previously reported characterization. ${ }^{32}$

Tert-butyl (2-(3,4-dichlorophenyl)-2-hydroxyethyl)carbamate (4). According to general procedure TP3 (method 1), 3 (1 eq., 1 g, $3.3 \mathrm{mmol}$ ) was treated with $\mathrm{NaBH}_{4}$ (4 eq., $0.5 \mathrm{~g}, 13.2 \mathrm{mmol}$ ) in $\mathrm{MeOH}(30 \mathrm{~mL}$ ) to afford 4 as a colorless oil $(1 \mathrm{~g}, 99 \%)$ without further purification. ${ }^{1} \mathrm{H}$ NMR $\left(400 \mathrm{MHz}, \mathrm{CDCl}_{3}\right): \delta 7.46(\mathrm{~d}, J=2.1$ $\mathrm{Hz}, 1 \mathrm{H}), 7.40(\mathrm{~d}, J=8.2 \mathrm{~Hz}, 1 \mathrm{H}), 7.19-7.15(\mathrm{~m}, 1 \mathrm{H}), 4.98(\mathrm{t}, J$ $=6.2 \mathrm{~Hz}, 1 \mathrm{H}), 4.79(\mathrm{dd}, J=7.7,3.2 \mathrm{~Hz}, 1 \mathrm{H}), 3.78(\mathrm{~s}, \mathrm{br}, 1 \mathrm{H})$, $3.49-3.38(\mathrm{~m}, 1 \mathrm{H}), 3.26-3.13(\mathrm{~m}, 1 \mathrm{H}), 1.43(\mathrm{~s}, 9 \mathrm{H}) .{ }^{13} \mathrm{C}\left\{{ }^{1} \mathrm{H}\right\}$ NMR $\left(101 \mathrm{MHz}, \mathrm{CDCl}_{3}\right): \delta 157.4,142.3,132.8,131.7,130.5$, 
128.1, 125.4, 80.5, 73.2, 48.5, 28.5. HRMS (ESI): $\mathrm{m} / \mathrm{z}$ calcd. for $\mathrm{C}_{13} \mathrm{H}_{17} \mathrm{Cl}_{2} \mathrm{NO}_{3}[\mathrm{M}+\mathrm{Na}]^{+}: 328.0483$, found: 328.0492 .

Tert-butyl (2-(3,4-dichlorophenyl)-2-((1,3-dioxoisoindolin-2yl)oxy)ethyl)carbamate (5). According to general procedure TP4, 4 (1 eq., $500 \mathrm{mg}, 1.6 \mathrm{mmol}$ ) was reacted with NHPI (1.5 eq., $400 \mathrm{mg}, 2.5 \mathrm{mmol}$ ), $\mathrm{PPh}_{3}(1.8$ eq., $771 \mathrm{mg}, 2.9 \mathrm{mmol})$ and DEAD (1.8 eq., $0.46 \mathrm{~mL}, 2.9 \mathrm{mmol})$ in THF $(15 \mathrm{~mL})$ at rt. The crude was purified by silica gel column chromatography (heptane:EtOAc $=5: 1)$ to afford 5 as a white solid $(693 \mathrm{mg}$, 94\%). ${ }^{1} \mathrm{H}$ NMR $\left(400 \mathrm{MHz}, \mathrm{CDCl}_{3}\right): \delta 7.84-7.78(\mathrm{~m}, 2 \mathrm{H}), 7.77-$ $7.73(\mathrm{~m}, 2 \mathrm{H}), 7.63(\mathrm{~s}, 1 \mathrm{H}), 7.45$ (d, $J=8.3 \mathrm{~Hz}, 1 \mathrm{H}), 7.38$ (dd, $J=$ 8.3, $2.1 \mathrm{~Hz}, 1 \mathrm{H}), 5.50(\mathrm{t}, J=6.2 \mathrm{~Hz}, 1 \mathrm{H}), 5.29(\mathrm{t}, J=5.3 \mathrm{~Hz}, 1 \mathrm{H})$, $3.61(\mathrm{dd}, J=7.3,5.0 \mathrm{~Hz}, 2 \mathrm{H}), 1.43(\mathrm{~s}, 9 \mathrm{H}) .{ }^{13} \mathrm{C}\left\{{ }^{1} \mathrm{H}\right\} \operatorname{NMR}(101$ $\left.\mathrm{MHz}, \mathrm{CDCl}_{3}\right): \delta 163.9,151.8,134.9,133.4,132.8,130.6,129.7$, $128.9,126.9,124.4,123.9,87.2,84.5,44.3,28.5$. HRMS (ESI): $\mathrm{m} / \mathrm{z}$ calcd. for $\mathrm{C}_{21} \mathrm{H}_{20} \mathrm{Cl}_{2} \mathrm{~N}_{2} \mathrm{O}_{5}[\mathrm{M}+\mathrm{Na}]^{+}:$473.0647, found: 473.0654.

\section{Tert-butyl}

(2-(aminooxy)-2-(3,4-

dichlorophenyl)ethyl)carbamate (6). According to general procedure TP5, 5 (1 eq., $400 \mathrm{mg}, 0.9 \mathrm{mmol}$ ), was reacted with hydrazine hydrate (15 eq., $0.64 \mathrm{~mL}, 13.3 \mathrm{mmol}$ ) in $\mathrm{EtOH}(15 \mathrm{~mL}$ ). The crude was purified by silica gel column chromatography (heptane:EtOAc $=2: 1)$ to afford 6 as a white solid $(268 \mathrm{mg}$, 94\%). ${ }^{1} \mathrm{H}$ NMR (400 MHz, $\left.\mathrm{CDCl}_{3}\right): \delta 7.46-7.41$ (m, 2H), 7.16 (dd, $J=8.2,1.8 \mathrm{~Hz}, 1 \mathrm{H}), 5.44$ (s, 2H), 4.86 (s, 1H), 4.60 (dd, $J=$ 7.9, $3.8 \mathrm{~Hz}, 1 \mathrm{H}), 3.56-3.44(\mathrm{~m}, 1 \mathrm{H}), 3.19$ (ddd, $J=14.4,7.9$, $4.8 \mathrm{~Hz}, 1 \mathrm{H}), 1.43(\mathrm{~s}, 9 \mathrm{H}) .{ }^{13} \mathrm{C}\left\{{ }^{1} \mathrm{H}\right\}$ NMR $\left(101 \mathrm{MHz}, \mathrm{CDCl}_{3}\right): \delta$ 155.9, 139.9, 133.0, 132.2, 130.7, 128.8, 126.2, 84.7, 79.8, 44.9, 28.5 .

\section{2-(aminooxy)-2-(3,4-dichlorophenyl)ethanamine}

dihydrochloride (7). According to general procedure TP6, 6 (1 eq., $100 \mathrm{mg}, 0.31 \mathrm{mmol}$ ) was treated with a solution of $\mathrm{HCl}$ in dioxane (4 M, $5 \mathrm{~mL})$ to afford 7 as a white solid (88 $\mathrm{mg}, 96 \%)$. ${ }^{1} \mathrm{H}$ NMR (400 MHz, DMSO-d $\left.d^{6}\right): \delta 10.48$ (s, br, 3H), 8.42 (s, br, $3 \mathrm{H}), 7.76-7.72(\mathrm{~m}, 2 \mathrm{H}), 7.46(\mathrm{dd}, J=8.3,2.0 \mathrm{~Hz}, 1 \mathrm{H}), 5.43$ (dd $J=8.6,4.0 \mathrm{~Hz}, 1 \mathrm{H}), 3.34-3.17(\mathrm{~m}, 2 \mathrm{H}) .{ }^{13} \mathrm{C}\left\{{ }^{1} \mathrm{H}\right\}$ NMR $(101$ $\left.\mathrm{MHz}, \mathrm{DMSO}-d^{6}\right): \delta 136.0,132.1,131.4,131.0,129.8,128.1$, $80.8,41.7$.

6-(3,4-dichlorophenyl)-5,6-dihydro-4H-1,2,4-oxadiazin-3amine (8) and 3-amino-6-(3,4-dichlorophenyl)-5,6-dihydro4H-1,2,4-oxadiazine-4-carbonitrile (9). According to general procedure TP7, 7 (1 eq., $50 \mathrm{mg}, 0.17 \mathrm{mmol}$ ) was dissolved in MeCN (10 mL), and treated successively with TEA (4 eq. 94.6 $\mu \mathrm{L}, 0.68 \mathrm{mmol}$ ) and a solution of $\operatorname{BrCN}(1.1$ eq., $19.8 \mathrm{mg}, 0.19$ $\mathrm{mmol})$ in $\mathrm{MeCN}(0.5 \mathrm{~mL})$ to afford $8(33.9 \mathrm{mg}, 81 \%)$ and $9(7.8$ $\mathrm{mg}, 17 \%$ ) as white solids after purification by reverse phase $\mathrm{C} 18$ column chromatography $\left(\mathrm{MeCN} / \mathrm{H}_{2} \mathrm{O}\right)$. Compounds 8 was recrystalized in $\mathrm{MeCN}$ at $4{ }^{\circ} \mathrm{C}$. Analytical data for Compound 8 ${ }^{1} \mathrm{H}$ NMR $\left(400 \mathrm{MHz}\right.$, DMSO-d $\left.\mathrm{d}^{6}\right): \delta 7.64-7.60(\mathrm{~m}, 2 \mathrm{H}), 7.35$ (dd, $J$ $=8.3,2.0 \mathrm{~Hz}, 1 \mathrm{H}), 6.16(\mathrm{~s}, 1 \mathrm{H}), 4.46(\mathrm{~s}, 2 \mathrm{H}), 4.42(\mathrm{dd}, J=9.0$, $3.2 \mathrm{~Hz}, 1 \mathrm{H}), 3.45$ (dd, $J=11.4,3.2 \mathrm{~Hz}, 1 \mathrm{H}), 3.15$ (dd, $J=11.4$, $9.0 \mathrm{~Hz}, 1 \mathrm{H}) .{ }^{13} \mathrm{C}\left\{{ }^{1} \mathrm{H}\right\} \mathrm{NMR}\left(101 \mathrm{MHz}\right.$, DMSO- $\left.d^{6}\right): \delta 154.1,140.4$, 130.9, 130.4, 130.3, 128.7, 127.0, 72.0, 45.3. HRMS (ESI): m/z calcd. for $\mathrm{C}_{9} \mathrm{H}_{10} \mathrm{Cl}_{2} \mathrm{~N}_{3} \mathrm{O}[\mathrm{M}+\mathrm{H}]^{+}$: 246.0201, found: 246.0208 . Analytical data for Compound $9{ }^{1} \mathrm{H}$ NMR $\left(400 \mathrm{MHz}\right.$, DMSO- $\left.d^{6}\right)$ : $\delta 7.72-7.65(\mathrm{~m}, 2 \mathrm{H}), 7.44-7.40(\mathrm{~m}, 1 \mathrm{H}), 5.78(\mathrm{~s}, 2 \mathrm{H}), 4.82(\mathrm{dd}$ $J=9.5,3.2 \mathrm{~Hz}, 1 \mathrm{H}), 4.10(\mathrm{dd}, J=11.0,3.2 \mathrm{~Hz}, 1 \mathrm{H}), 3.97(\mathrm{dd}, J$ $=11.0,9.5 \mathrm{~Hz}, 1 \mathrm{H}) \cdot{ }^{13} \mathrm{C}\left\{{ }^{1} \mathrm{H}\right\} \mathrm{NMR}\left(101 \mathrm{MHz}, \mathrm{DMSO}-d^{6}\right): \delta 147.2$, 137.2, 131.3, 131.2, 130.7, 129.1, 127.3, 109.7, 72.1, 50.7. HRMS (ESI): $\mathrm{m} / \mathrm{z}$ calcd. for $\mathrm{C}_{10} \mathrm{H}_{9} \mathrm{Cl}_{2} \mathrm{~N}_{4} \mathrm{O}[\mathrm{M}+\mathrm{H}]^{+}:$271.0153, found: 271.0156 .

(S)-tert-butyl (1-oxo-1-phenylpropan-2-yl)carbamate (10).

Step 1: (S)-tert-butyl (1-(methoxy(methyl)amino)-1-oxopropan-2$\mathrm{yl}$ )carbamate (36). Following general procedure TP1 and starting from $N$-Boc- $L$-alanine ( 1 eq., $4 \mathrm{~g}, 21.1 \mathrm{mmol}$ ), CDI 1.5 eq., 5.14 $\mathrm{g}, 31.7 \mathrm{mmol}$ ), TEA (1.5 eq, $4.41 \mathrm{~mL}, 31.7 \mathrm{mmol}$ ) and $\mathrm{N}, \mathrm{O}$ dimethylhydroxylamine hydrochloride $(1.5$ eq., $3.1 \mathrm{~g}, 31.7 \mathrm{mmol})$ in DCM $(50 \mathrm{~mL})$, the Weinreb amide of $N$-Boc- $L$-alanine $\mathbf{3 6}$ was obtained as a white solid (4.67 g, 95\%). ${ }^{1} \mathrm{H}$ NMR $(400 \mathrm{MHz}$, $\left.\mathrm{CDCl}_{3}\right): \delta 5.25(\mathrm{~d}, J=7.1 \mathrm{~Hz}, 1 \mathrm{H}), 4.73-4.57(\mathrm{~m}, 1 \mathrm{H}), 3.74(\mathrm{~s}$, $3 \mathrm{H}$ ), 3.18 (s, 3H), 1.41 (s, 9H), 1.28 (d, J=6.9 Hz, 3H). The analytical data are consistent with the previously reported characterization. ${ }^{33}$

Step 2: (S)-tert-butyl (1-oxo-1-phenylpropan-2-yl)carbamate (10). According to general procedure TP2, phenyl magnesium bromide (1.5 eq., $1 \mathrm{M}, 12.9 \mathrm{~mL}, 12.9 \mathrm{mmol}$ ) was reacted with the above described Weinreb amide of $N$-Boc- $L$-alanine 36 ( 1 eq., 2 $\mathrm{g}, 8.6 \mathrm{mmol})$ in THF $(25 \mathrm{~mL})$. After work-up, the crude was purified by silica gel column chromatography (heptane:EtOAc = $10: 1)$ to afford 10 as as a colorless oil $(1.93 \mathrm{~g}, 90 \%)$. ${ }^{1} \mathrm{H}$ NMR $\left(400 \mathrm{MHz}, \mathrm{CDCl}_{3}\right)$ : $\delta 7.99-7.94(\mathrm{~m}, 2 \mathrm{H}), 7.61-7.55(\mathrm{~m}, 1 \mathrm{H})$, $7.51-7.44(\mathrm{~m}, 2 \mathrm{H}), 5.57(\mathrm{~d}, J=7.7 \mathrm{~Hz}, 1 \mathrm{H}), 5.35-5.21(\mathrm{~m}$, $1 \mathrm{H}), 1.45(\mathrm{~s}, 9 \mathrm{H}), 1.39(\mathrm{~d}, J=7.1 \mathrm{~Hz}, 3 \mathrm{H})$. The analytical data are consistent with the previously reported characterization. ${ }^{34}$

(S)-tert-butyl (3-methyl-1-oxo-1-phenylbutan-2-yl)carbamate (11).

Step 1: (S)-tert-butyl (1-(methoxy(methyl)amino)-3-methyl-1oxobutan-2-yl)carbamate (37). Following general procedure TP1 and starting from $N$-Boc- $L$-valine (1 eq., $4 \mathrm{~g}, 18.4 \mathrm{mmol}$ ), CDI (1.5 eq., $4.48 \mathrm{~g}, 27.6 \mathrm{mmol}$ ), TEA (1.5 eq, $3.84 \mathrm{~mL}, 27.6 \mathrm{mmol})$ and $\mathrm{N}, \mathrm{O}$-dimethylhydroxylamine hydrochloride (1.5 eq., $2.69 \mathrm{~g}$, $27.6 \mathrm{mmol})$ in DCM $(50 \mathrm{~mL})$, the Weinreb amide of $N$-Boc- $L$ valine 37 was obtained as a white solid $(4.51 \mathrm{~g}, 94 \%) .{ }^{1} \mathrm{H}$ NMR (400 MHz, $\mathrm{CDCl}_{3}$ ): $\delta 5.12$ (d, $J=9.4 \mathrm{~Hz}, 1 \mathrm{H}$ ), 4.55 (t, $J=8.0 \mathrm{~Hz}$, $1 \mathrm{H}), 3.74(\mathrm{~s}, 3 \mathrm{H}), 3.19(\mathrm{~s}, 3 \mathrm{H}), 1.96(\mathrm{dq}, J=13.4,6.7 \mathrm{~Hz}, 1 \mathrm{H})$, $1.41(\mathrm{~s}, 9 \mathrm{H}), 0.93(\mathrm{~d}, J=6.8 \mathrm{~Hz}, 3 \mathrm{H}), 0.88(\mathrm{~d}, J=6.8 \mathrm{~Hz}, 3 \mathrm{H})$. The analytical data are consistent with the previously reported characterization. ${ }^{35}$

Step 2: (S)-tert-butyl (3-methyl-1-oxo-1-phenylbutan-2$\mathrm{yl}$ )carbamate (11). According to general procedure TP2, phenyl magnesium bromide (1.5 eq., $1 \mathrm{M}, 11.5 \mathrm{~mL}, 11.5 \mathrm{mmol}$ ) was reacted with the above described Weinreb amide of $N$-Boc- $L$ valine 37 (1 eq., $2 \mathrm{~g}, 7.7 \mathrm{mmol}$ ) in THF (25 mL). After work-up, the crude was purified by silica gel column chromatography (heptane:EtOAc $=10: 1)$ to afford 11 as as a colorless oil (1.88 g, $88 \%) .{ }^{1} \mathrm{H}$ NMR $\left(400 \mathrm{MHz}, \mathrm{CDCl}_{3}\right)$ : $\delta 8.01-7.87(\mathrm{~m}, 2 \mathrm{H}), 7.63-$ $7.54(\mathrm{~m}, 1 \mathrm{H}), 7.48(\mathrm{td}, J=7.5,1.4 \mathrm{~Hz}, 2 \mathrm{H}), 5.43(\mathrm{~d}, J=8.6 \mathrm{~Hz}$, $1 \mathrm{H}), 5.23(\mathrm{dd}, J=9.1,4.1 \mathrm{~Hz}, 1 \mathrm{H}), 2.24-2.03(\mathrm{~m}, 1 \mathrm{H}), 1.45(\mathrm{~s}$, $9 \mathrm{H}), 1.03(\mathrm{~d}, J=6.8 \mathrm{~Hz}, 3 \mathrm{H}), 0.75(\mathrm{~d}, J=6.8 \mathrm{~Hz}, 3 \mathrm{H})$. The analytical data are consistent with the previously reported characterization.$^{36}$

(S)-tert-butyl 2-benzoylpyrrolidine-1-carboxylate (12).

Step 1: (S)-tert-butyl 2-(methoxy(methyl)carbamoyl)pyrrolidine1-carboxylate (38). Following general procedure TP1 and starting from $N$-Boc-L-proline (1 eq., $4 \mathrm{~g}, 18.6 \mathrm{mmol}$ ), CDI (1.5 eq., $4.52 \mathrm{~g}, 27.9 \mathrm{mmol}$ ), TEA (1.5 eq, $3.88 \mathrm{~mL}, 27.9 \mathrm{mmol})$ and N,O-dimethylhydroxylamine hydrochloride (1.5 eq., $2.72 \mathrm{~g}, 27.9$ $\mathrm{mmol}$ ) in DCM (50 mL), the Weinreb amide of N-Boc-L-proline 38 was obtained as a white solid $(4.51 \mathrm{~g}, 94 \%)$. ${ }^{1} \mathrm{H}$ NMR (400 $\mathrm{MHz}, \mathrm{CDCl}_{3}$ ): $\delta 4.63$ (ddd, $J=41.1,8.6,3.4 \mathrm{~Hz}, 1 \mathrm{H}$ ), 3.76 (s, $1.5 \mathrm{H}), 3.69(\mathrm{~s}, 1.5 \mathrm{H}), 3.61-3.32(\mathrm{~m}, 2 \mathrm{H}), 3.17(\mathrm{~s}, 3 \mathrm{H}), 2.25-$ $2.08(\mathrm{~m}, 1 \mathrm{H}), 1.99-1.77(\mathrm{~m}, 3 \mathrm{H}), 1.43(\mathrm{~s}, 4.5 \mathrm{H}), 1.39(\mathrm{~s}, 4.5 \mathrm{H})$. The analytical data are consistent with the previously reported characterization. ${ }^{37}$

Step 2: (S)-tert-butyl 2-benzoylpyrrolidine-1-carboxylate (12). According to general procedure TP2, phenyl magnesium bromide (1.5 eq., $1 \mathrm{M}, 11.6 \mathrm{~mL}, 11.6 \mathrm{mmol}$ ) was reacted with the above described Weinreb amide of $N$-Boc- $L$-proline 38 (1 eq., 2 
g, $7.7 \mathrm{mmol})$ in THF (25 mL). After work-up, the crude was purified by silica gel column chromatography (heptane:EtOAc = 10:1) to afford 12 as a colorless oil $(1.87 \mathrm{~g}, 88 \%)$. ${ }^{1} \mathrm{H}$ NMR (400 $\left.\mathrm{MHz}, \mathrm{CDCl}_{3}\right): \delta 8.04-7.87(\mathrm{~m}, 2 \mathrm{H}), 7.61-7.50(\mathrm{~m}, 1 \mathrm{H}), 7.50-$ $7.40(\mathrm{~m}, 2 \mathrm{H}), 5.39-5.27(\mathrm{~m}, 0.4 \mathrm{H}), 5.24-5.14(\mathrm{~m}, 0.6 \mathrm{H}), 3.74$ $-3.41(\mathrm{~m}, 2 \mathrm{H}), 2.40-2.18(\mathrm{~m}, 1 \mathrm{H}), 2.01-1.84(\mathrm{~m}, 3 \mathrm{H}), 1.45(\mathrm{~s}$, $3.5 \mathrm{H}), 1.25(\mathrm{~s}, 5.5 \mathrm{H})$. The analytical data are consistent with the previously reported characterization. ${ }^{37}$

Tert-butyl

((1R,2S)-1-hydroxy-1-phenylpropan-2yl)carbamate (13a). According to general procedure TP3 (method 2), 10 (1 eq., $1 \mathrm{~g}, 4 \mathrm{mmol}$ ) dissolved in THF (10 mL) was treated with DIBAL-H (2 eq., $1 \mathrm{M}, 8 \mathrm{~mL}, 8 \mathrm{mmol}$ ) without further purification to afford $13 \mathrm{a}$ as a colorless oil $(1 \mathrm{~g}, 99 \%) .{ }^{1} \mathrm{H}$ $\operatorname{NMR}\left(400 \mathrm{MHz}, \mathrm{CDCl}_{3}\right)$ : $\delta 7.37-7.26(\mathrm{~m}, 5 \mathrm{H}), 4.85(\mathrm{~d}, J=3.0$ $\mathrm{Hz}, 1 \mathrm{H}), 4.64$ (s, 1H), 4.01 (s, 1H), 3.26 (s, br, 1H), 1.46 (s, 9H), $0.98(\mathrm{~d}, J=7.0 \mathrm{~Hz}, 3 \mathrm{H})$. The analytical data are consistent with the previously reported characterization. ${ }^{38}$

Tert-butyl

((1S,2S)-1-hydroxy-1-phenylpropan-2-

yl)carbamate (13b). According to general procedure TP3 (method 3), 10 (1 eq., $1 \mathrm{~g}, 4 \mathrm{mmol}$ ) was dissolved in THF (10 $\mathrm{mL}$ ) and was treated with borane dimethylsulfide complex (2 eq. $0.76 \mathrm{~mL}, 8 \mathrm{mmol}$ ) and a solution of $(R)$-2-Me-CBSoxazaborolidine $(0.1$ eq. $0.11 \mathrm{~g}, 4 \mathrm{mmol})$ in THF $(10 \mathrm{~mL})$ to afford $13 \mathrm{~b}$ as a colorless oil $(0.728 \mathrm{~g}, 71 \%)$ after purification by silica gel column chromatography (heptane:EtOAc $=10: 1) .{ }^{1} \mathrm{H}$ NMR $\left(400 \mathrm{MHz}, \mathrm{CDCl}_{3}\right): \delta 7.35-7.26(\mathrm{~m}, 5 \mathrm{H}), 4.70(\mathrm{~s}, 1 \mathrm{H})$, $4.54(\mathrm{~d}, J=6.0 \mathrm{~Hz}, 1 \mathrm{H}), 3.93-3.79(\mathrm{~m}, 1 \mathrm{H}), 3.27(\mathrm{~s}, \mathrm{br}, 1 \mathrm{H})$, $1.40(\mathrm{~s}, 9 \mathrm{H}), 1.07$ (d, $J=6.8 \mathrm{~Hz}, 3 \mathrm{H})$. The analytical data are consistent with the previously reported characterization. ${ }^{39}$

Tert-butyl ((1R,2S)-1-hydroxy-3-methyl-1-phenylbutan-2yl)carbamate (14a). According to general procedure TP3 (method 2), 11 (1 eq., $1 \mathrm{~g}, 3.6 \mathrm{mmol}$ ) dissolved in THF (10 mL) was treated with DIBAL-H (2 eq., $1 \mathrm{M}, 7.2 \mathrm{~mL}, 7.2 \mathrm{mmol}$ ) without further purification to afford $14 \mathrm{a}$ as a colorless oil $(0.98 \mathrm{~g}, 97 \%)$. ${ }^{1} \mathrm{H}$ NMR $\left(400 \mathrm{MHz}, \mathrm{CDCl}_{3}\right)$ : $\delta 7.35-7.27(\mathrm{~m}, 5 \mathrm{H}), 4.87(\mathrm{t}, \mathrm{J}=$ $4.6 \mathrm{~Hz}, 1 \mathrm{H}), 4.35(\mathrm{~d}, J=9.8 \mathrm{~Hz}, 1 \mathrm{H}), 3.83-3.74(\mathrm{~m}, 1 \mathrm{H}), 3.05$ $(\mathrm{d}, J=4.5 \mathrm{~Hz}, 1 \mathrm{H}), 1.78-1.66(\mathrm{~m}, 1 \mathrm{H}), 1.39(\mathrm{~s}, 9 \mathrm{H}), 1.04(\mathrm{~d}, J$ $=6.7 \mathrm{~Hz}, 3 \mathrm{H}), 0.89(\mathrm{~d}, J=6.7 \mathrm{~Hz}, 3 \mathrm{H})$. These data are consistent with the previously reported characterization. ${ }^{20}$

Tert-butyl ((1S,2S)-1-hydroxy-3-methyl-1-phenylbutan-2yl)carbamate (14b). According to general procedure TP3 (method 4), 11 (1 eq., $1 \mathrm{~g}, 3.6 \mathrm{mmol})$ in THF (10 mL) was added to a suspension of $\mathrm{LiAlH}_{4}(2$ eq., $1 \mathrm{M}, 7.2 \mathrm{~mL}, 7.2 \mathrm{mmol}$ ) to afford $14 \mathrm{~b}$ as a colorless oil $(0.47 \mathrm{~g}, 47 \%)$ after purification by silica gel column chromatography (heptane:EtOAc $=10: 1$ ). ${ }^{1} \mathrm{H}$ NMR $\left(400 \mathrm{MHz}, \mathrm{CDCl}_{3}\right)$ : $\delta 7.36-7.31(\mathrm{~m}, 5 \mathrm{H}), 4.83-4.76(\mathrm{~m}$, $2 \mathrm{H}), 3.52-3.40(\mathrm{~m}, 1 \mathrm{H}), 2.96(\mathrm{~d}, J=4.4 \mathrm{~Hz}, 1 \mathrm{H}), 1.90-1.79$ $(\mathrm{m}, 1 \mathrm{H}), 1.36(\mathrm{~s}, 9 \mathrm{H}), 1.01(\mathrm{~d}, J=6.8 \mathrm{~Hz}, 3 \mathrm{H}), 0.94(\mathrm{~d}, J=6.8$ $\mathrm{Hz}, 3 \mathrm{H})$. The analytical data are consistent with the previously reported characterization. ${ }^{40}$

(S)-tert-butyl 2-((R)-hydroxy(phenyl)methyl)pyrrolidine-1carboxylate (15a). According to general procedure TP3 (method 2), 12 (1 eq., $1 \mathrm{~g}, 3.6 \mathrm{mmol}$ ) in THF (10 mL) was treated with DIBAL-H (2 eq., $1 \mathrm{M}, 7.3 \mathrm{~mL}, 7.3 \mathrm{mmol}$ ) without further purification to afford $15 \mathrm{a}$ as a colorless oil $(1 \mathrm{~g}, 99 \%) .{ }^{1} \mathrm{H}$ NMR $\left(400 \mathrm{MHz}, \mathrm{CDCl}_{3}\right)$ : $\delta 7.37-7.25(\mathrm{~m}, 5 \mathrm{H}), 5.47(\mathrm{~s}, 0.7 \mathrm{H})$, $5.18(\mathrm{~s}, 0.3 \mathrm{H}), 4.89(\mathrm{~s}, 0.7 \mathrm{H}), 4.33(\mathrm{~s}, 0.7 \mathrm{H}), 4.02(\mathrm{~s}, 0.3 \mathrm{H}), 3.58$ $(\mathrm{s}, 0.3 \mathrm{H}), 3.31(\mathrm{~s}, 1 \mathrm{H}), 2.84(\mathrm{~s}, 0.7 \mathrm{H}), 2.36-2.14(\mathrm{~m}, 0.3 \mathrm{H})$, $1.98-1.88(\mathrm{~m}, 1 \mathrm{H}), 1.79(\mathrm{~s}, 1 \mathrm{H}), 1.54(\mathrm{~s}, 9 \mathrm{H}), 1.26-1.16(\mathrm{~m}$, $1 \mathrm{H}), 0.95-0.8(\mathrm{~m}, 1 \mathrm{H})$. The analytical data are consistent with the previously reported characterization. ${ }^{41}$

(S)-tert-butyl 2-((S)-hydroxy(phenyl)methyl)pyrrolidine-1carboxylate (15b). According to general procedure TP3 (Method 1), 12 (1 eq., $1 \mathrm{~g}, 3.6 \mathrm{mmol}$ ) was dissolved in $\mathrm{MeOH}$
(30 mL) and treated with $\mathrm{NaBH}_{4}$ (4 eq., $0.55 \mathrm{~g}, 14.5 \mathrm{mmol}$ ) to afford $15 \mathrm{~b}$ as a colorless oil $(0.73 \mathrm{~g}, 72 \%)$. after purification by reverse phase $\mathrm{C} 18$ column chromatography $\left(\mathrm{MeOH} / \mathrm{H}_{2} \mathrm{O}\right) .{ }^{1} \mathrm{H}$ NMR $\left(400 \mathrm{MHz}, \mathrm{CDCl}_{3}\right): \delta 7.35-7.24(\mathrm{~m}, 5 \mathrm{H}), 5.81(\mathrm{~s}, 0.7 \mathrm{H})$, $5.41(\mathrm{~s}, 0.3 \mathrm{H}), 5.16-4.60(\mathrm{~m}, 1 \mathrm{H}), 4.56-4.21(\mathrm{~m}, 1 \mathrm{H}), 4.12-$ $4.00(\mathrm{~m}, 0.8 \mathrm{H}), 3.53-3.16(\mathrm{~m}, 2 \mathrm{H}), 2.79(\mathrm{~s}, 0.2 \mathrm{H}), 1.75-1.58$ $(\mathrm{m}, 3 \mathrm{H}), 1.48(\mathrm{~s}, 9 \mathrm{H})$. The analytical data are consistent with the previously reported characterization. ${ }^{41}$

Tert-butyl ((1S,2S)-1-((1,3-dioxoisoindolin-2-yl)oxy)-1phenylpropan-2-yl)carbamate (16a). According to general procedure TP4, 13a (1 eq., $500 \mathrm{mg}, 2 \mathrm{mmol}$ ) was reacted with NHPI (1.5 eq., $487 \mathrm{mg}, 3 \mathrm{mmol}$ ), $\mathrm{PPh}_{3}$ (1.8 eq., $939 \mathrm{mg}, 3.6$ $\mathrm{mmol}$ ) and DEAD (1.8 eq., $0.56 \mathrm{~mL}, 3.6 \mathrm{mmol})$ in THF (15 mL) at $0^{\circ} \mathrm{C}$. The crude was purified by silica gel column chromatography (heptane:EtOAc $=5: 1$ ) to afford $16 \mathrm{a}$ as a white solid (702 mg, 89\%). ${ }^{1} \mathrm{H}$ NMR $\left(400 \mathrm{MHz}, \mathrm{CDCl}_{3}\right)$ : $\delta 7.76-7.71$ $(\mathrm{m}, 2 \mathrm{H}), 7.70-7.65(\mathrm{~m}, 2 \mathrm{H}), 7.49-7.43(\mathrm{~m}, 2 \mathrm{H}), 7.37-7.30$ $(\mathrm{m}, 3 \mathrm{H}), 5.22(\mathrm{~d}, J=6.5 \mathrm{~Hz}, 1 \mathrm{H}), 5.13(\mathrm{~s}, 1 \mathrm{H}), 4.18(\mathrm{q}, J=7.0$ $\mathrm{Hz}, 1 \mathrm{H}), 1.42(\mathrm{~s}, 9 \mathrm{H}), 1.20(\mathrm{~d}, J=6.8 \mathrm{~Hz}, 3 \mathrm{H}) .{ }^{13} \mathrm{C}\left\{{ }^{1} \mathrm{H}\right\}$ NMR $(101$ $\left.\mathrm{MHz}, \mathrm{CDCl}_{3}\right): \delta 163.7,155.4,135.6,134.5,129.2,129.0,128.4$, 128.4, 123.6, 90.9, 79.5, 50.1, 28.5, 17.9. HRMS (ESI): $\mathrm{m} / \mathrm{z}$ calcd. for $\mathrm{C}_{22} \mathrm{H}_{24} \mathrm{~N}_{2} \mathrm{O}_{5}[\mathrm{M}+\mathrm{Na}]^{+}: 419.1590$, found: 419.1583 .

Tert-butyl ((1R,2S)-1-((1,3-dioxoisoindolin-2-yl)oxy)-1phenylpropan-2-yl)carbamate (16b). According to general procedure TP4, 13b (1 eq., $500 \mathrm{mg}, 2 \mathrm{mmol}$ ) was reacted with NHPI (2 eq., $649 \mathrm{mg}, 4 \mathrm{mmol}), \mathrm{PPh}_{3}$ (2.5 eq., $1.3 \mathrm{~g}, 5 \mathrm{mmol}$ ) and DEAD (2.5 eq., $0.78 \mathrm{~mL}, 5 \mathrm{mmol})$ in THF $(20 \mathrm{~mL})$ at rt. The crude was purified by silica gel column chromatography (heptane:EtOAc $=5: 1)$ to afford $\mathbf{1 6 b}$ as a colorless oil $(757 \mathrm{mg}$, 96\%). ${ }^{1} \mathrm{H}$ NMR (400 MHz, $\left.\mathrm{CDCl}_{3}\right): \delta 7.77-7.72(\mathrm{~m}, 2 \mathrm{H}), 7.71-$ $7.67(\mathrm{~m}, 2 \mathrm{H}), 7.56(\mathrm{~d}, J=7.5 \mathrm{~Hz}, 2 \mathrm{H}), 7.39-7.27(\mathrm{~m}, 3 \mathrm{H}), 5.43$ $(\mathrm{s}, 1 \mathrm{H}), 5.40(\mathrm{~s}, 1 \mathrm{H}), 4.06(\mathrm{~s}, 1 \mathrm{H}), 1.43(\mathrm{~s}, 9 \mathrm{H}), 1.24(\mathrm{~d}, J=7.0$ $\mathrm{Hz}, 3 \mathrm{H}) .{ }^{13} \mathrm{C}\left\{{ }^{1} \mathrm{H}\right\} \mathrm{NMR}\left(101 \mathrm{MHz}, \mathrm{CDCl}_{3}\right): \delta 163.8,155.4,136.3$, 134.6, 129.0, 128.6, 128.2, 127.6, 123.6, 91.5, 79.5, 51.1, 28.5, 14.2. HRMS (ESI): $\mathrm{m} / \mathrm{z}$ calcd. for $\mathrm{C}_{22} \mathrm{H}_{24} \mathrm{~N}_{2} \mathrm{O}_{5}[\mathrm{M}+\mathrm{Na}]^{+}$: 419.1583, found: 419.1590 .

Tert-butyl ((1S,2S)-1-((1,3-dioxoisoindolin-2-yl)oxy)-3methyl-1-phenylbutan-2-yl)carbamate (17a). According to general procedure TP4, 14a (1 eq., $500 \mathrm{mg}, 1.8 \mathrm{mmol}$ ) was treated with NHPI (1.5 eq., $438 \mathrm{mg}, 2.7 \mathrm{mmol}$ ), $\mathrm{PPh}_{3}$ (1.8 eq., $845 \mathrm{mg}, 3.2 \mathrm{mmol}$ ) and DEAD (1.8 eq., $0.51 \mathrm{~mL}, 3.2 \mathrm{mmol}$ ) in THF $(15 \mathrm{~mL})$ at $0{ }^{\circ} \mathrm{C}$. The crude was purified by silica gel column chromatography (heptane:EtOAc $=4: 1$ ), to afford $17 \mathrm{a}$ as a white solid $(615 \mathrm{mg}, 81 \%)$. ${ }^{1} \mathrm{H}$ NMR $\left(400 \mathrm{MHz}, \mathrm{CDCl}_{3}\right): \delta 7.72-7.64$ $(\mathrm{m}, 4 \mathrm{H}), 7.51-7.47(\mathrm{~m}, 2 \mathrm{H}), 7.33-7.27(\mathrm{~m}, 3 \mathrm{H}), 5.52(\mathrm{~d}, J=$ $4.8 \mathrm{~Hz}, 1 \mathrm{H}$ ), 5.12 (d, $J=10.2 \mathrm{~Hz}, 1 \mathrm{H}$ ), 3.81 (ddd, $J=10.1,6.8$, $4.7 \mathrm{~Hz}, 1 \mathrm{H}), 1.98-1.86(\mathrm{~m}, 1 \mathrm{H}), 1.39(\mathrm{~s}, 9 \mathrm{H}), 1.15(\mathrm{~d}, J=6.7$ $\mathrm{Hz}, 3 \mathrm{H}), 0.95(\mathrm{~d}, J=6.8 \mathrm{~Hz}, 3 \mathrm{H}) .{ }^{13} \mathrm{C}\left\{{ }^{1} \mathrm{H}\right\}$ NMR $(101 \mathrm{MHz}$, $\left.\mathrm{CDCl}_{3}\right): \delta 163.7,156.1,136.5,134.5,129.0,128.9,128.3,128.1$, 123.5, 88.2, 79.2, 60.0, 30.6, 28.5, 20.3, 18.5. HRMS (ESI): m/z calcd. for $\mathrm{C}_{24} \mathrm{H}_{28} \mathrm{~N}_{2} \mathrm{O}_{5}[\mathrm{M}+\mathrm{Na}]^{+}:$447.1896, found: 447.1902 .

Tert-butyl ((1S,2S)-1-((1,3-dioxoisoindolin-2-yl)oxy)-3methyl-1-phenylbutan-2-yl)carbamate (17b). According to general procedure TP4, 14b (1 eq., $400 \mathrm{mg}, 1.4 \mathrm{mmol}$ ) with was treated NHPI (3 eq., $700 \mathrm{mg}, 4.3 \mathrm{mmol}$ ), $\mathrm{PPh}_{3}$ (3.5 eq., $1.3 \mathrm{~g}, 5$ mmol) and DEAD (1.8 eq., $0.79 \mathrm{~mL}, 5 \mathrm{mmol})$ in THF $(15 \mathrm{~mL})$ at $45^{\circ} \mathrm{C}$ in an oil bath. The crude was purified by silica gel column chromatography (heptane:EtOAc $=5: 1$ ) to afford $17 \mathrm{~b}$ as a white solid (450 mg, 74\%). ${ }^{1} \mathrm{H}$ NMR $\left(400 \mathrm{MHz}, \mathrm{CDCl}_{3}\right)$ : $\delta 7.72-7.67$ $(\mathrm{m}, 2 \mathrm{H}), 7.67-7.64(\mathrm{~m}, 2 \mathrm{H}), 7.53-7.46(\mathrm{~m}, 2 \mathrm{H}), 7.33-7.26$ $(\mathrm{m}, 3 \mathrm{H}), 5.36(\mathrm{~d}, J=7.6 \mathrm{~Hz}, 1 \mathrm{H}), 4.50(\mathrm{~d}, J=10.7 \mathrm{~Hz}, 1 \mathrm{H}), 4.24$ - $4.15(\mathrm{~m}, 1 \mathrm{H}), 2.32-2.19(\mathrm{~m}, 1 \mathrm{H}), 1.28(\mathrm{~s}, 7 \mathrm{H}), 1.26(\mathrm{~s}, 2 \mathrm{H})$, $1.08(\mathrm{~d}, J=6.8 \mathrm{~Hz}, 3 \mathrm{H}), 1.02(\mathrm{~d}, J=6.8 \mathrm{~Hz}, 3 \mathrm{H}) .{ }^{13} \mathrm{C}\left\{{ }^{1} \mathrm{H}\right\} \mathrm{NMR}$ $\left(101 \mathrm{MHz}, \mathrm{CDCl}_{3}\right): \delta 163.6,155.6,135.8,134.4,129.1,128.9$, 
128.8, 128.1, 123.5, 89.3, 79.3, 57.7, 28.3, 28.1, 20.6, 16.4 HRMS (ESI): $\mathrm{m} / \mathrm{z}$ calcd. for $\mathrm{C}_{24} \mathrm{H}_{28} \mathrm{~N}_{2} \mathrm{O}_{5}[\mathrm{M}+\mathrm{Na}]^{+}: 447.1896$, found: 447.1902 .

(S)-tert-butyl 2-((R)-((1,3-dioxoisoindolin-2yl)oxy)(phenyl)methyl)pyrrolidine-1-carboxylate (18a).

According to general procedure TP4, 15a (1 eq., $500 \mathrm{mg}, 1.8$ mmol) was treated with NHPI (1.5 eq., $441 \mathrm{mg}, 2.7 \mathrm{mmol}$ ), $\mathrm{PPh}_{3}$ (1.8 eq., $851 \mathrm{mg}, 3.2 \mathrm{mmol}$ ) and DEAD (1.8 eq., $0.51 \mathrm{~mL}, 3.2$ $\mathrm{mmol})$ in THF $(15 \mathrm{~mL})$ at $0{ }^{\circ} \mathrm{C}$. The crude was purified by silica gel column chromatography (heptane:EtOAc $=4: 1$ ), to afford 18a as a white solid $(716 \mathrm{mg}, 94 \%) .{ }^{1} \mathrm{H}$ NMR $\left(400 \mathrm{MHz}, \mathrm{CDCl}_{3}\right)$ : ס $7.72-7.38(\mathrm{~m}, 6 \mathrm{H}), 7.30-7.19(\mathrm{~m}, 3 \mathrm{H}), 5.88(\mathrm{~s}, 0.4 \mathrm{H}), 5.68$ $(\mathrm{s}, 0.6 \mathrm{H}), 4.03(\mathrm{~m}, 1 \mathrm{H}), 3.59-3.32(\mathrm{~m}, 2 \mathrm{H}), 2.50-2.19(\mathrm{~m}, 1 \mathrm{H})$, $2.05(\mathrm{~m}, 1 \mathrm{H}), 1.75(\mathrm{~m}, 2 \mathrm{H}), 1.40(\mathrm{~s}, 4 \mathrm{H}), 1.36(\mathrm{~s}, 5 \mathrm{H}) .{ }^{13} \mathrm{C}\left\{{ }^{1} \mathrm{H}\right\}$ NMR $\left(101 \mathrm{MHz}, \mathrm{CDCl}_{3}\right): \delta 163.6,154.8,134.4,129.2,128.6$, $128.2,127.8,127.5,123.5,88.9,77.4,61.8,46.8,29.9,22.8$, 14.3. HRMS (ESI): $\mathrm{m} / \mathrm{z}$ calcd. for $\mathrm{C}_{24} \mathrm{H}_{26} \mathrm{~N}_{2} \mathrm{O}_{5}[\mathrm{M}+\mathrm{Na}]^{+}$: 445.1740, found: 445.1746 .

(5S,6S)-5-methyl-6-phenyl-5,6-dihydro-4H-1,2,4-oxadiazin-3amine (19a).

Step 1: tert-butyl ((1S,2S)-1-(aminooxy)-1-phenylpropan-2$\mathrm{yl})$ carbamate (39a). According to general procedure TP5, 16a (1 eq., $400 \mathrm{mg}, 1 \mathrm{mmol})$ in $\mathrm{EtOH}(15 \mathrm{~mL})$ was treated with hydrazine hydrate (15 eq., $0.73 \mathrm{~mL}, 15.1 \mathrm{mmol}$ ). The crude was purified by silica gel column chromatography (heptane:EtOAc = $2: 1)$ to afford tert-butyl $((1 S, 2 S)$-1-(aminooxy)-1-phenylpropan-2$\mathrm{yl})$ carbamate $39 \mathrm{a}$ as a colorless oil $(245 \mathrm{mg}, 91 \%) .{ }^{1} \mathrm{H}$ NMR $\left(400 \mathrm{MHz}, \mathrm{CDCl}_{3}\right): \delta 7.40-7.33(\mathrm{~m}, 2 \mathrm{H}), 7.33-7.26(\mathrm{~m}, 3 \mathrm{H})$, $5.32(\mathrm{~s}, 2 \mathrm{H}), 4.64-4.53(\mathrm{~m}, 1 \mathrm{H}), 4.49(\mathrm{~d}, J=5.6 \mathrm{~Hz}, 1 \mathrm{H}), 3.99$ $(\mathrm{s}, 1 \mathrm{H}), 1.40(\mathrm{~s}, 9 \mathrm{H}), 1.05(\mathrm{~d}, J=6.8 \mathrm{~Hz}, 3 \mathrm{H}) .{ }^{13} \mathrm{C}\left\{{ }^{1} \mathrm{H}\right\}$ NMR $(101$ $\left.\mathrm{MHz}, \mathrm{CDCl}_{3}\right): \delta 155.5,138.6,128.6,128.1,127.5,89.1,79.4$, 49.9, 28.5, 17.6 .

Step 2: (1S,2S)-1-(aminooxy)-1-phenylpropan-2-amine dihydrochloride (40a). According to general procedure TP6, tertbutyl ((1S,2S)-1-(aminooxy)-1-phenylpropan-2-yl)carbamate 39a (1 eq., $100 \mathrm{mg}, 0.38 \mathrm{mmol}$ ) was treated with a hydrogen chloride solution in dioxane $(4 \mathrm{M}, 5 \mathrm{~mL})$ to afford $(1 S, 2 S)$-1-(aminooxy)1-phenylpropan-2-amine dihydrochloride $40 \mathrm{a}$ as a white solid (89.8 mg, 100\%). ${ }^{1} \mathrm{H}$ NMR (400 MHz, DMSO-d $d^{6}$ ): $\delta 10.79$ (s, br, $3 \mathrm{H}), 8.56(\mathrm{~s}, \mathrm{br}, 3 \mathrm{H}), 7.57-7.34(\mathrm{~m}, 5 \mathrm{H}), 5.17(\mathrm{~d}, J=9.1 \mathrm{~Hz}$, $1 \mathrm{H}), 3.58(\mathrm{dt}, J=13.6,6.8 \mathrm{~Hz}, 1 \mathrm{H}), 0.93(\mathrm{~d}, J=6.8 \mathrm{~Hz}, 3 \mathrm{H})$. ${ }^{13} \mathrm{C}\left\{{ }^{1} \mathrm{H}\right\} \quad \mathrm{NMR}\left(101 \mathrm{MHz}\right.$, DMSO- $\left.d^{6}\right): \delta 134.1,129.7,128.9$, 128.3, 86.4, 49.3, 15.1

Step 3: $\quad(5 S, 6 S)-5$-methyl-6-phenyl-5,6-dihydro-4H-1,2,4oxadiazin-3-amine (19a). According to general procedure TP7, the above (1S,2S)-1-(aminooxy)-1-phenylpropan-2-amine dihydrochloride 40 a (1 eq., $50 \mathrm{mg}, 0.21 \mathrm{mmol}$ ) was dissolved in MeCN (10 mL) and treated successively with TEA (4 eq. 116.2 $\mu \mathrm{L}, 0.84 \mathrm{mmol}$ ) and a solution of $\operatorname{BrCN}(1.1$ eq., $24.4 \mathrm{mg}, 0.23$ $\mathrm{mmol})$ in $\mathrm{MeCN}(0.5 \mathrm{~mL})$ to afford the title compound 19a (28.4 $\mathrm{mg}, 71 \%$ ) as a white solid after purification by reverse phase C18 column chromatography $\left(\mathrm{MeCN} / \mathrm{H}_{2} \mathrm{O}\right)$. Compounds $19 \mathrm{a}$ was recrystalized in MeCN at $4{ }^{\circ} \mathrm{C}$. ${ }^{1} \mathrm{H}$ NMR $(400 \mathrm{MHz}$, DMSO$\left.d^{6}\right): \delta 7.39-7.27(\mathrm{~m}, 5 \mathrm{H}), 6.10(\mathrm{~s}, 1 \mathrm{H}), 4.39(\mathrm{~s}, 2 \mathrm{H}), 3.82(\mathrm{~d}, J=$ $8.5 \mathrm{~Hz}, 1 \mathrm{H}), 3.40-3.34(\mathrm{~m}, 1 \mathrm{H}), 0.84(\mathrm{~d}, J=6.3 \mathrm{~Hz}, 3 \mathrm{H}) .{ }^{13} \mathrm{C}\left\{{ }^{1} \mathrm{H}\right\}$ NMR (101 MHz, DMSO- $\left.d^{6}\right)$ : $\delta 153.9,138.4,128.2,128.1,127.7$, 80.9, 50.7, 17.6. HRMS (ESI): $\mathrm{m} / \mathrm{z}$ calcd. for $\mathrm{C}_{10} \mathrm{H}_{14} \mathrm{~N}_{3} \mathrm{O}[\mathrm{M}+\mathrm{H}]^{+}$: 192.1137, found: 192.1139 .

(5S,6R)-5-methyl-6-phenyl-5,6-dihydro-4H-1,2,4-oxadiazin-3amine (19b).

Step 1: tert-butyl ((1R,2S)-1-(aminooxy)-1-phenylpropan-2$\mathrm{yl}$ )carbamate (39b). According to general procedure TP5, 16b (1 eq., $400 \mathrm{mg}, 1 \mathrm{mmol})$ in $\mathrm{EtOH}(15 \mathrm{~mL})$ was treated with hydrazine hydrate (15 eq., $0.73 \mathrm{~mL}, 15.1 \mathrm{mmol}$ ). The crude was purified by silica gel column chromatography (heptane:EtOAc = $2: 1)$ to afford tert-butyl ((1R,2S)-1-(aminooxy)-1-phenylpropan-2$\mathrm{yl}$ )carbamate $39 \mathrm{~b}$ as a colorless oil $(258 \mathrm{mg}, 96 \%) .{ }^{1} \mathrm{H}$ NMR $\left(400 \mathrm{MHz}, \mathrm{CDCl}_{3}\right)$ : $\delta 7.39-7.32(\mathrm{~m}, 2 \mathrm{H}), 7.31-7.26(\mathrm{~m}, 3 \mathrm{H})$, $5.50(\mathrm{~s}, \mathrm{br}, 2 \mathrm{H}), 4.78-4.65(\mathrm{~m}, 1 \mathrm{H}), 4.61(\mathrm{~d}, J=3.4 \mathrm{~Hz}, 1 \mathrm{H})$, $4.15-4.00(\mathrm{~m}, 1 \mathrm{H}), 1.45(\mathrm{~s}, 9 \mathrm{H}), 0.98(\mathrm{~d}, J=7.0 \mathrm{~Hz}, 3 \mathrm{H})$. ${ }^{13} \mathrm{C}\left\{{ }^{1} \mathrm{H}\right\}$ NMR $\left(101 \mathrm{MHz}, \mathrm{CDCl}_{3}\right): \delta 155.6,138.2,128.5,127.9$, 127.1, 89.1, 79.3, 49.2, 28.6, 15.5 .

Step 2: $\quad(1 R, 2 S)-1$-(aminooxy)-1-phenylpropan-2-amine dihydrochloride (40b). According to general procedure TP6, tertbutyl ((1R,2S)-1-(aminooxy)-1-phenylpropan-2-yl)carbamate 39b (1 eq., $100 \mathrm{mg}, 0.38 \mathrm{mmol}$ ) was treated with a hydrogen chloride solution in dioxane $(4 \mathrm{M}, 5 \mathrm{~mL})$ to afford $(1 R, 2 S)$-1-(aminooxy)1-phenylpropan-2-amine dihydrochloride $40 \mathrm{~b}$ as a white solid (88.9 mg, 99\%). ${ }^{1} \mathrm{H}$ NMR (400 MHz, DMSO-d ${ }^{6}$ ): $\delta 10.99$ (s, br, $3 \mathrm{H}), 8.46(\mathrm{~s}, \mathrm{br}, 3 \mathrm{H}), 7.51-7.38(\mathrm{~m}, 5 \mathrm{H}), 5.47(\mathrm{~d}, J=3.8 \mathrm{~Hz}$, 1H), 3.59 (dt, $J=7.0,3.1 \mathrm{~Hz}, 1 \mathrm{H}), 1.08(\mathrm{~d}, J=6.9 \mathrm{~Hz}, 3 \mathrm{H})$. ${ }^{13} \mathrm{C}\left\{{ }^{1} \mathrm{H}\right\}$ NMR $(101 \mathrm{MHz}$, DMSO-d $)$ : $\delta 134.4,129.0,128.7,126.9$, 84.6, 50.0, 12.4 .

Step 3: $\quad(5 S, 6 R)-5$-methyl-6-phenyl-5,6-dihydro-4H-1,2,4oxadiazin-3-amine (19b). According to general procedure TP7, the above (1R,2S)-1-(aminooxy)-1-phenylpropan-2-amine dihydrochloride $40 \mathrm{~b}$ ( 1 eq., $50 \mathrm{mg}, 0.21 \mathrm{mmol}$ ) was dissolved in MeCN (10 mL) and treated successively with TEA (4 eq. 116.2 $\mu \mathrm{L}, 0.84 \mathrm{mmol}$ ) and a solution of $\operatorname{BrCN}(1.1$ eq., $24.4 \mathrm{mg}, 0.23$ $\mathrm{mmol}$ ) in MeCN (0.5 mL) to afford $19 \mathrm{~b}(27.6 \mathrm{mg}, 69 \%)$ as a white solid after purification by reverse phase $\mathrm{C} 18$ column chromatography $\left(\mathrm{MeCN} / \mathrm{H}_{2} \mathrm{O}\right) .{ }^{1} \mathrm{H}$ NMR $\left(400 \mathrm{MHz}\right.$, DMSO- $\left.d^{6}\right)$ : $\delta$ $7.36-7.22(\mathrm{~m}, 5 \mathrm{H}), 6.25(\mathrm{~s}, 1 \mathrm{H}), 4.55(\mathrm{~d}, J=3.0 \mathrm{~Hz}, 1 \mathrm{H}), 4.39$ (s, 2H), $3.73-3.63(\mathrm{~m}, 1 \mathrm{H}), 0.74(\mathrm{~d}, J=6.4 \mathrm{~Hz}, 3 \mathrm{H}) .{ }^{13} \mathrm{C}\left\{{ }^{1} \mathrm{H}\right\}$ NMR (101 MHz, DMSO- $\left.d^{6}\right)$ : $\delta$ 154.0, 138.7, 127.9, 126.9, 125.8, 76.3, 48.4, 16.7. HRMS (ESI): $\mathrm{m} / \mathrm{z}$ calcd. for $\mathrm{C}_{10} \mathrm{H}_{14} \mathrm{~N}_{3} \mathrm{O}[\mathrm{M}+\mathrm{H}]^{+}$: 192.1137, found: 191.1134 .

(5S,6S)-5-isopropyl-6-phenyl-5,6-dihydro-4H-1,2,4-oxadiazin3-amine (20a).

Step 1: tert-butyl ((1S,2S)-1-(aminooxy)-3-methyl-1phenylbutan-2-yl)carbamate (41a). According to general procedure TP5, 17a (1 eq., $400 \mathrm{mg}, 0.94 \mathrm{mmol}$ ) in EtOH (15 mL) was treated with hydrazine hydrate (15 eq., $0.69 \mathrm{~mL}, 14.1 \mathrm{mmol}$ ). The crude was purified by silica gel column chromatography (heptane:EtOAc $=2: 1)$ to afford tert-butyl $((1 S, 2 S)$-1-(aminooxy)3-methyl-1-phenylbutan-2-yl)carbamate 41a as a white solid (266 mg, 96\%). ${ }^{1} \mathrm{H}$ NMR (400 MHz, $\left.\mathrm{CDCl}_{3}\right): \delta 7.35-7.29(\mathrm{~m}$, $5 \mathrm{H}), 5.29(\mathrm{~s}, 2 \mathrm{H}), 4.72(\mathrm{~d}, J=10.4 \mathrm{~Hz}, 1 \mathrm{H}), 4.63(\mathrm{~d}, J=4.9 \mathrm{~Hz}$, $1 \mathrm{H}), 3.63-3.53(\mathrm{~m}, 1 \mathrm{H}), 1.79-1.69(\mathrm{~m}, 1 \mathrm{H}), 1.34(\mathrm{~s}, 9 \mathrm{H}), 1.00$ $(\mathrm{d}, J=6.7 \mathrm{~Hz}, 3 \mathrm{H}), 0.90(\mathrm{~d}, J=6.8 \mathrm{~Hz}, 3 \mathrm{H}) .{ }^{13} \mathrm{C}\left\{{ }^{1} \mathrm{H}\right\} \operatorname{NMR}(101$ $\left.\mathrm{MHz}, \mathrm{CDCl}_{3}\right)$ : $\delta 156.1,139.7,128.6,127.9,127.0,86.8,79.0$, 60.0, 30.1, 28.5, 20.3, 18.3.

Step 2: (1S,2S)-1-(aminooxy)-3-methyl-1-phenylbutan-2-amine dihydrochloride (42a). According to general procedure TP6, tertbutyl ((1S,2S)-1-(aminooxy)-3-methyl-1-phenylbutan-2$\mathrm{yl})$ carbamate $41 \mathrm{a}$ ( 1 eq., $100 \mathrm{mg}, 0.34 \mathrm{mmol}$ ) was treated with a hydrogen chloride solution in dioxane $(4 \mathrm{M}, 5 \mathrm{~mL})$ to afford (1S,2S)-1-(aminooxy)-3-methyl-1-phenylbutan-2-amine

dihydrochloride $42 \mathrm{a}$ as a white solid $(85.3 \mathrm{mg}, 94 \%) .{ }^{1} \mathrm{H}$ NMR (400 MHz, DMSO-d6): $\delta 9.02(\mathrm{~s}, \mathrm{br}, 6 \mathrm{H}), 7.50-7.46(\mathrm{~m}, 5 \mathrm{H})$, $5.25(\mathrm{~d}, J=9.9 \mathrm{~Hz}, 1 \mathrm{H}), 3.44$ (dd, $J=9.9,2.5 \mathrm{~Hz}, 1 \mathrm{H}), 1.48-$ $1.36(\mathrm{~m}, 1 \mathrm{H}), 0.93(\mathrm{~d}, J=7.1 \mathrm{~Hz}, 3 \mathrm{H}), 0.81(\mathrm{~d}, J=7.0 \mathrm{~Hz}, 3 \mathrm{H})$. ${ }^{13} \mathrm{C}\left\{{ }^{1} \mathrm{H}\right\}$ NMR $\left(101 \mathrm{MHz}\right.$, DMSO-d $\left.d^{6}\right): \delta 129.8,129.8,128.9,128.4$, 84.7, 58.1, 27.1, 19.1, 15.1.

Step 3: (5S,6S)-5-isopropyl-6-phenyl-5,6-dihydro-4H-1,2,4oxadiazin-3-amine (20a). According to general procedure TP7, the above (1S,2S)-1-(aminooxy)-3-methyl-1-phenylbutan-2amine dihydrochloride 42a (1 eq., $50 \mathrm{mg}, 0.19 \mathrm{mmol}$ ) was 
dissolved in MeCN $(10 \mathrm{~mL})$ and treated successively with TEA (4 eq. $104 \mu \mathrm{L}, 0.75 \mathrm{mmol}$ ) and a solution of $\operatorname{BrCN}(1.1$ eq., 21.8 $\mathrm{mg}, 0.21 \mathrm{mmol})$ in $\mathrm{MeCN}(0.5 \mathrm{~mL})$ to afford $20 \mathrm{a}$ (30 mg, 73\%) as a white solid after purification by reverse phase $\mathrm{C} 18$ column chromatography $\left(\mathrm{MeCN} / \mathrm{H}_{2} \mathrm{O}\right) .{ }^{1} \mathrm{H}$ NMR $\left(400 \mathrm{MHz}\right.$, DMSO- $\left.d^{6}\right)$ : $\delta$ $7.43-7.28(\mathrm{~m}, 5 \mathrm{H}), 5.86(\mathrm{~s}, 1 \mathrm{H}), 4.44(\mathrm{~s}, 2 \mathrm{H}), 4.09(\mathrm{~d}, J=8.2$ $\mathrm{Hz}, 1 \mathrm{H}), 3.34-3.31(\mathrm{~m}, 1 \mathrm{H}), 1.47-1.36(\mathrm{~m}, 1 \mathrm{H}), 0.86(\mathrm{~d}, J=$ $7.1 \mathrm{~Hz}, 3 \mathrm{H}), 0.79(\mathrm{~d}, J=6.8 \mathrm{~Hz}, 3 \mathrm{H}) .{ }^{13} \mathrm{C}\left\{{ }^{1} \mathrm{H}\right\} \mathrm{NMR}(101 \mathrm{MHz}$, DMSO- $\left.d^{6}\right): \delta$ 155.0, 138.8, 128.2, 128.0, 127.8, 77.0, 59.6, 28.2, 19.3, 15.1 HRMS (ESI): $\mathrm{m} / \mathrm{z}$ calcd. for $\mathrm{C}_{12} \mathrm{H}_{18} \mathrm{~N}_{3} \mathrm{O}[\mathrm{M}+\mathrm{H}]^{+}$: 220.1450, found: 220.1454 .

\section{(5S,6R)-5-isopropyl-6-phenyl-5,6-dihydro-4H-1,2,4-} oxadiazin-3-amine (20b).

Step 1: tert-butyl ((1R,2S)-1-(aminooxy)-3-methyl-1phenylbutan-2-yl)carbamate (41b). According to general procedure TP5, 17b (1 eq., $400 \mathrm{mg}, 0.94 \mathrm{mmol}$ ) in EtOH (15 $\mathrm{mL}$ ) was treated with hydrazine hydrate (15 eq., $0.69 \mathrm{~mL}, 14.1$ $\mathrm{mmol})$. The crude was purified by silica gel column chromatography (heptane:EtOAc $=2: 1$ ) to afford tert-butyl ((1R,2S)-1-(aminooxy)-3-methyl-1-phenylbutan-2-yl)carbamate 41b as a colorless oil (236 mg, 85\%). ${ }^{1} \mathrm{H}$ NMR $(400 \mathrm{MHz}$, $\left.\mathrm{CDCl}_{3}\right)$ : $\delta 7.37-7.29(\mathrm{~m}, 5 \mathrm{H}), 5.50(\mathrm{~s}, 2 \mathrm{H}), 4.63(\mathrm{~d}, J=5.5 \mathrm{~Hz}$, $1 \mathrm{H}), 4.31(\mathrm{~d}, J=10.8 \mathrm{~Hz}, 1 \mathrm{H}), 3.96-3.86(\mathrm{~m}, 1 \mathrm{H}), 1.75-1.64$ $(\mathrm{m}, 1 \mathrm{H}), 1.36(\mathrm{~s}, 9 \mathrm{H}), 1.00(\mathrm{~d}, J=6.8 \mathrm{~Hz}, 3 \mathrm{H}), 0.87(\mathrm{~d}, J=6.8$ $\mathrm{Hz}, 3 \mathrm{H}) .{ }^{13} \mathrm{C}\left\{{ }^{1} \mathrm{H}\right\}$ NMR $\left(101 \mathrm{MHz}, \mathrm{CDCl}_{3}\right): \delta 156.1,138.5,128.5$, 128.0, 127.6, 87.4, 79.1, 57.7, 28.5, 28.4, 20.8, 17.9 .

Step 2: (1R,2S)-1-(aminooxy)-3-methyl-1-phenylbutan-2-amine dihydrochloride (42b). According to general procedure TP6, tertbutyl ((1R,2S)-1-(aminooxy)-3-methyl-1-phenylbutan-2yl)carbamate $41 \mathrm{~b}$ ( 1 eq., $100 \mathrm{mg}, 0.34 \mathrm{mmol}$ ) was treated with a hydrogen chloride solution in dioxane $(4 \mathrm{M}, 5 \mathrm{~mL})$ to afford $(1 R, 2 S)$-1-(aminooxy)-3-methyl-1-phenylbutan-2-amine dihydrochloride $\mathbf{4 2 b}$ as a white solid $(90.8 \mathrm{mg}, 94 \%) .{ }^{1} \mathrm{H}$ NMR (400 MHz, DMSO-d $d^{6}$ ): $\delta 10.74$ (s, br, 3H), 8.15 (s, br, 3H), $7.51-$ $7.43(\mathrm{~m}, 5 \mathrm{H}), 5.48(\mathrm{~d}, J=5.1 \mathrm{~Hz}, 1 \mathrm{H}), 3.51-3.48(\mathrm{~m}, 1 \mathrm{H}), 1.82$ $-1.75(\mathrm{~m}, 1 \mathrm{H}), 1.00(\mathrm{~d}, J=6.9 \mathrm{~Hz}, 3 \mathrm{H}), 0.97(\mathrm{~d}, J=6.9 \mathrm{~Hz}, 3 \mathrm{H})$. ${ }^{13} \mathrm{C}\left\{{ }^{1} \mathrm{H}\right\}$ NMR $\left(101 \mathrm{MHz}, \mathrm{DMSO}-d^{6}\right): \delta 129.2,129.2,128.8,127.7$ 83.5, 58.2, 26.8, 19.7, 17.7 .

Step 3: $(5 S, 6 R)$-5-isopropyl-6-phenyl-5,6-dihydro-4H-1,2,4oxadiazin-3-amine (20b). According to general procedure TP7, the above (1R,2S)-1-(aminooxy)-3-methyl-1-phenylbutan-2amine dihydrochloride $42 \mathrm{~b}$ (1 eq., $50 \mathrm{mg}, 0.19 \mathrm{mmol}$ ) was dissolved in MeCN (10 mL) and treated successively with TEA (4 eq. $104 \mu \mathrm{L}, 0.75 \mathrm{mmol}$ ) and a solution of $\operatorname{BrCN}(1.1$ eq., 21.8 $\mathrm{mg}, 0.21 \mathrm{mmol})$ in $\mathrm{MeCN}(0.5 \mathrm{~mL})$ to afford $20 \mathrm{~b}(27.1 \mathrm{mg}, 66 \%)$ as a white solid after purification by reverse phase $\mathrm{C} 18$ column chromatography $\left(\mathrm{MeCN} / \mathrm{H}_{2} \mathrm{O}\right) .{ }^{1} \mathrm{H}$ NMR $\left(400 \mathrm{MHz}\right.$, DMSO-d $\left.d^{6}\right): \delta$ $7.37-7.22(\mathrm{~m}, 5 \mathrm{H}), 6.21(\mathrm{~d}, J=5.0 \mathrm{~Hz}, 1 \mathrm{H}), 4.61(\mathrm{~d}, J=3.6 \mathrm{~Hz}$, $1 \mathrm{H}), 4.37(\mathrm{~s}, 2 \mathrm{H}), 3.42(\mathrm{dt}, J=5.1,3.5 \mathrm{~Hz}, 1 \mathrm{H}), 1.35-1.26(\mathrm{~m}$, $1 \mathrm{H}), 0.78(\mathrm{~d}, J=6.6 \mathrm{~Hz}, 3 \mathrm{H}), 0.70(\mathrm{~d}, J=6.9 \mathrm{~Hz}, 3 \mathrm{H}) .{ }^{13} \mathrm{C}\left\{{ }^{1} \mathrm{H}\right\}$ NMR $\left(101 \mathrm{MHz}\right.$, DMSO- $\left.d^{6}\right): \delta 154.3,138.6,127.9,126.9,125.9$, 76.4, 57.3, 28.0, 21.1, 17.1. HRMS (ESI): $\mathrm{m} / \mathrm{z}$ calcd. for $\mathrm{C}_{12} \mathrm{H}_{18} \mathrm{~N}_{3} \mathrm{O}[\mathrm{M}+\mathrm{H}]^{+}: 220.1450$, found: 220.1453 .

\section{(1R,8aS)-1-phenyl-6,7,8,8a-tetrahydro-1 $H$-pyrrolo[1,2-}

\section{d] $[1,2,4]$ oxadiazin-4-amine (21).}

$\begin{array}{llll}\text { Step } & \text { 1: } & (S) \text {-tert-butyl } & \text { 2- }((R)-\end{array}$
(aminooxy)(phenyl)methyl)pyrrolidine-1-carboxylate (43). According to general procedure TP5, 18a (1 eq., $400 \mathrm{mg}, 0.95$ $\mathrm{mmol}$ ) in $\mathrm{EtOH}(15 \mathrm{~mL})$ was treated with hydrazine hydrate (15 eq., $0.69 \mathrm{~mL}, 14.2 \mathrm{mmol}$ ). The crude was purified by silica gel column chromatography (heptane:EtOAc $=2: 1$ ) to afford $(S)$-tertbutyl 2-((R)-(aminooxy)(phenyl)methyl)pyrrolidine-1-carboxylate 43 as a colorless oil (269 mg, 97\%). ${ }^{1} \mathrm{H}$ NMR (400 MHz, $\left.\mathrm{CDCl}_{3}\right)$ : $\delta 7.42-7.27(\mathrm{~m}, 5 \mathrm{H}), 5.43(\mathrm{~s}, 2 \mathrm{H}), 5.01(\mathrm{~d}, J=44.7 \mathrm{~Hz}, 1 \mathrm{H})$, $4.00(\mathrm{~d}, J=96.9 \mathrm{~Hz}, 1 \mathrm{H}), 3.61-3.26(\mathrm{~m}, 2 \mathrm{H}), 2.13-1.70(\mathrm{~m}$ $3 \mathrm{H}), 1.63(\mathrm{~m}, 1 \mathrm{H}), 1.52-1.46(\mathrm{~m}, 9 \mathrm{H}) .{ }^{13} \mathrm{C}\left\{{ }^{1} \mathrm{H}\right\} \mathrm{NMR}(101 \mathrm{MHz}$, $\left.\mathrm{CDCl}_{3}\right): \delta 154.6,140.0,128.6,127.6,126.4,88.1,79.7,62.0$, 47.0, 28.7, 25.8, 23.7.

Step 2: $O-((R)$-phenyl ((S)-pyrrolidin-2-yl)methyl)hydroxylamine dihydrochloride (44). According to general procedure TP6, $(S)$ tert-butyl 2-((R)-(aminooxy)(phenyl)methyl)pyrrolidine-1carboxylate 43 (1 eq., $100 \mathrm{mg}, 0.34 \mathrm{mmol}$ ) was treated with a hydrogen chloride solution in dioxane $(4 \mathrm{M}, 5 \mathrm{~mL})$ to afford $O$ ((R)-phenyl((S)-pyrrolidin-2-yl)methyl)hydroxylamine dihydrochloride 44 as a white solid (97.1 mg, 96\%). ${ }^{1} \mathrm{H}$ NMR (400 MHz, DMSO-d6): $\delta 10.53$ (s, br, 3H), 9.79 (s, br, 2H), $7.62-$ $7.31(\mathrm{~m}, 5 \mathrm{H}), 5.59(\mathrm{~d}, J=5.0 \mathrm{~Hz}, 1 \mathrm{H}), 3.95-3.76(\mathrm{~m}, 1 \mathrm{H}), 3.24$ - $3.06(\mathrm{~m}, 2 \mathrm{H}), 2.04-1.71(\mathrm{~m}, 4 \mathrm{H}) .{ }^{13} \mathrm{C}\left\{{ }^{1} \mathrm{H}\right\}$ NMR $(101 \mathrm{MHz}$, DMSO- $\left.d^{6}\right): \delta 135.1,129.1,128.8,127.0,83.2,61.7,45.4,24.6$, 23.5.

Step 3: (1R,8aS)-1-phenyl-6,7,8,8a-tetrahydro-1 $H$-pyrrolo[1,2d] $[1,2,4]$ oxadiazin-4-amine (21). According to general procedure TP7, the above $O-((R)$-phenyl $((S)$-pyrrolidin-2-yl)methyl) hydroxylamine dihydrochloride 44 (1 eq., $50 \mathrm{mg}, 0.19 \mathrm{mmol}$ ) in MeCN (10 mL) was treated successively with TEA (4 eq. $105 \mu \mathrm{L}$, $0.75 \mathrm{mmol}$ ) and a solution of $\mathrm{BrCN}(1.1$ eq., $22 \mathrm{mg}, 0.21 \mathrm{mmol})$ in $\mathrm{MeCN}(0.5 \mathrm{~mL})$ to afford 21 (38.5 mg, 94\%) as a white solid after purification by reverse phase $\mathrm{C} 18$ column chromatography $\left(\mathrm{MeCN} / \mathrm{H}_{2} \mathrm{O}\right)$. Compounds 21 was recrystalized in $\mathrm{MeCN}$ at $4{ }^{\circ} \mathrm{C}$. ${ }^{1} \mathrm{H}$ NMR $\left(400 \mathrm{MHz}\right.$, DMSO-d $\left.\mathrm{d}^{6}\right)$ : $7.41-7.16(\mathrm{~m}, 5 \mathrm{H}), 4.98$ (d, J $=4.3 \mathrm{~Hz}, 1 \mathrm{H}), 4.79(\mathrm{~s}, 2 \mathrm{H}), 3.67$ (ddd, $J=9.5,5.5,4.4 \mathrm{~Hz}, 1 \mathrm{H})$, $3.32-3.24(\mathrm{~m}, 2 \mathrm{H}), 1.68-1.47(\mathrm{~m}, 3 \mathrm{H}), 1.31-1.08(\mathrm{~m}, 1 \mathrm{H})$. ${ }^{13} \mathrm{C}\left\{{ }^{1} \mathrm{H}\right\}$ NMR (101 MHz, DMSO-d $\left.d^{6}\right): \delta 155.3,138.7,127.9,127.2$, 127.1, 75.4, 58.0, 47.4, 27.0, 22.5. HRMS (ESI): $\mathrm{m} / \mathrm{z}$ calcd. for $\mathrm{C}_{12} \mathrm{H}_{16} \mathrm{~N}_{3} \mathrm{O}[\mathrm{M}+\mathrm{H}]^{+}:$218.1293, found: 218.1288 .

(S)-2-((R)-(aminooxy)(phenyl)methyl)pyrrolidine-1-

carbonitrile (22). To a solution of $O-((R)$-phenyl $((S)$-pyrrolidin-2yl)methyl)hydroxylamine dihydrochloride (1 eq., $15 \mathrm{mg}, 0.057$ $\mathrm{mmol}$ ) in $\mathrm{MeCN}(3 \mathrm{~mL})$ at $0{ }^{\circ} \mathrm{C}$, TEA (4 eq., $\left.31.4 \mu \mathrm{L}, 0.23 \mathrm{mmol}\right)$ was added dropwise and stirred for $5 \mathrm{~min}$. Then a solution of $\operatorname{BrCN}$ (1.1 eq., $6.6 \mathrm{mg}, 0.062 \mathrm{mmol}$ ) in $\mathrm{MeCN}(0.2 \mathrm{~mL}$ ) was added dropwise and stirring was maintained for an additional 30 min while the temperature was kept at $0^{\circ} \mathrm{C}$. The mixture was concentrated in vacuo and the crude was purified by reverse phase $\mathrm{C} 18$ column chromatography $\left(\mathrm{MeOH} / \mathrm{H}_{2} \mathrm{O}\right)$ to afford 22 (8.4 mg, 68\%) as a white solid. ${ }^{1} \mathrm{H}$ NMR (400 MHz, DMSO-d $): \delta$ $7.39-7.30(\mathrm{~m}, 5 \mathrm{H}), 6.05(\mathrm{~s}, 2 \mathrm{H}), 4.54(\mathrm{~d}, J=4.0 \mathrm{~Hz}, 1 \mathrm{H}), 3.92$ (ddd, $J=7.7,5.2,4.1 \mathrm{~Hz}, 1 \mathrm{H}), 3.28-3.12(\mathrm{~m}, 2 \mathrm{H}), 1.81-1.63$ $(\mathrm{m}, 3 \mathrm{H}), 1.42-1.32(\mathrm{~m}, 1 \mathrm{H}) .{ }^{13} \mathrm{C}\left\{{ }^{1} \mathrm{H}\right\}$ NMR $(101 \mathrm{MHz}$, DMSO$\left.d^{6}\right): \delta 138.7,128.1,127.6,127.4,117.0,86.1,64.2,51.2,26.2$, 23.9. HRMS (ESI): $\mathrm{m} / \mathrm{z}$ calcd. for $\mathrm{C}_{12} \mathrm{H}_{16} \mathrm{~N}_{3} \mathrm{O}[\mathrm{M}+\mathrm{H}]^{+}: 218.1293$, found: 218.1289 .

Tert-butyl (3-methyl-2-oxobut-3-en-1-yl)carbamate (26). According to general procedure TP2, 2 (1 eq., $2 \mathrm{~g}, 9.2 \mathrm{mmol}$ ) in THF $(10 \mathrm{~mL})$ was treated with isopropenyl magnesium bromide (3.5 eq., $0.5 \mathrm{M}, 64.2 \mathrm{~mL}, 32.1 \mathrm{mmol}$ ) to afford 26 as a colorless oil without further purification (1.81 g, 99\%). ${ }^{1} \mathrm{H}$ NMR $(400 \mathrm{MHz}$, $\left.\mathrm{CDCl}_{3}\right): \delta 5.99(\mathrm{~s}, 1 \mathrm{H}), 5.83(\mathrm{q}, J=1.4 \mathrm{~Hz}, 1 \mathrm{H}), 5.36(\mathrm{~s}, 1 \mathrm{H})$, 4.35 (d, $J=4.7 \mathrm{~Hz}, 2 \mathrm{H}), 1.90(\mathrm{t}, J=1.2 \mathrm{~Hz}, 3 \mathrm{H}), 1.44(\mathrm{~s}, 9 \mathrm{H})$. ${ }^{13} \mathrm{C}\left\{{ }^{1} \mathrm{H}\right\}$ NMR $\left(101 \mathrm{MHz}, \mathrm{CDCl}_{3}\right): \delta 196.1,155.9,142.5,125.5$ $79.9,46.7,28.5,17.5$.

Tert-butyl (2-hydroxy-3-methylbut-3-en-1-yl)carbamate (27). According to general procedure TP3 (method 5), 26 (1 eq., $1 \mathrm{~g}$, $5 \mathrm{mmol})$ was dissolved in $\mathrm{MeOH}(30 \mathrm{~mL})$ and treated with trichlorocerium heptahydrate (1.6 eq., $3 \mathrm{~g}, 8 \mathrm{mmol}$ ) and $\mathrm{NaBH}_{4}$ (1.5 eq., $0.28 \mathrm{~g}, 7.5 \mathrm{mmol}$ ). The crude was purified by silica gel column chromatography (heptane:EtOAc $=2: 1$ ) to afford 27 as a colorless oil $(0.84 \mathrm{~g}, 83 \%)$. ${ }^{1} \mathrm{H}$ NMR $\left(400 \mathrm{MHz}, \mathrm{CDCl}_{3}\right): \delta 5.04$ 
(dt, $J=1.9,1.0 \mathrm{~Hz}, 1 \mathrm{H}), 4.96-4.83(\mathrm{~m}, 2 \mathrm{H}), 4.14(\mathrm{dt}, J=7.3$, $3.4 \mathrm{~Hz}, 1 \mathrm{H}$ ), $3.44-3.31$ (m, 1H), 3.11 (ddd, $J=13.5,7.5,5.3 \mathrm{~Hz}$ $1 \mathrm{H}), 2.64(\mathrm{~s}, \mathrm{br}, 1 \mathrm{H}), 1.74(\mathrm{t}, J=1.2 \mathrm{~Hz}, 3 \mathrm{H}), 1.44(\mathrm{~s}, 9 \mathrm{H}) .{ }^{13} \mathrm{C}\left\{{ }^{1} \mathrm{H}\right\}$ NMR $\left(101 \mathrm{MHz}, \mathrm{CDCl}_{3}\right): \delta 157.0,145.2,111.8,79.8,75.1,45.2$, 28.5, 18.7. HRMS (ESI): $\mathrm{m} / \mathrm{z}$ calcd. for $\mathrm{C}_{10} \mathrm{H}_{19} \mathrm{NNaO}_{3}[\mathrm{M}+\mathrm{Na}]^{+}$: 224.1263, found: 224.1259 .

Tert-butyl (2-((1,3-dioxoisoindolin-2-yl)oxy)-3-methylbut-3en-1-yl)carbamate (28). According to general procedure TP4, 27 (1 eq., $500 \mathrm{mg}, 2.5 \mathrm{mmol}$ ) was dissolved in THF (15 mL) and treated with NHPI (1.5 eq., $608 \mathrm{mg}, 3.7 \mathrm{mmol}$ ), $\mathrm{PPh}_{3}$ (1.8 eq., $1.2 \mathrm{~g}, 4.5 \mathrm{mmol}$ ) and DEAD (1.8 eq., $0.7 \mathrm{~mL}, 4.5 \mathrm{mmol}$ ) at rt. The crude was purified by silica gel column chromatography (heptane:EtOAc $=4: 1)$ to afford 28 as a colorless oil $(818 \mathrm{mg}$, 95\%). ${ }^{1} \mathrm{H}$ NMR (400 MHz, $\left.\mathrm{CDCl}_{3}\right)$ : $\delta 7.86-7.66(\mathrm{~m}, 4 \mathrm{H}), 5.42(\mathrm{~s}$, $1 \mathrm{H}), 5.09-4.97(\mathrm{~m}, 2 \mathrm{H}), 4.70-4.55(\mathrm{~m}, 1 \mathrm{H}), 3.55-3.38(\mathrm{~m}$, $2 \mathrm{H}), 1.92$ (s, 3H), 1.46 (s, 9H). ${ }^{13} \mathrm{C}\left\{{ }^{1} \mathrm{H}\right\}$ NMR (101 MHz, $\left.\mathrm{CDCl}_{3}\right)$ : ठ 163.9, 156.2, 140.3, 134.7, 128.9, 123.7, 117.7, 90.7, 79.6, 42.0, 28.5, 17.9. HRMS (ESI): $\mathrm{m} / \mathrm{z}$ calcd. for $\mathrm{C}_{18} \mathrm{H}_{22} \mathrm{~N}_{2} \mathrm{O}_{5}[\mathrm{M}+$ $\mathrm{Na}^{+}:$369.1427, found: 369.1436 .

Tert-butyl (2-(aminooxy)-3-methylbut-3-en-1-yl)carbamate (29). According to general procedure TP5, 28 (1 eq., $400 \mathrm{mg}$, $1.16 \mathrm{mmol})$ was dissolved in $\mathrm{EtOH}(15 \mathrm{~mL})$ and treated with hydrazine hydrate $(15$ eq., $0.84 \mathrm{~mL}, 17.32 \mathrm{mmol}$ ). The crude was purified by silica gel column chromatography (heptane:EtOAc $=1: 1)$ to afford 29 as a colorless oil $(245 \mathrm{mg}$, 98\%). ${ }^{1} \mathrm{H}$ NMR (400 MHz, $\mathrm{CDCl}_{3}$ ): 5.31 (s, br, 2H), $5.04-4.99$ $(\mathrm{m}, 2 \mathrm{H}), 4.85(\mathrm{~s}, 1 \mathrm{H}), 3.96(\mathrm{dd}, J=7.7,3.9 \mathrm{~Hz}, 1 \mathrm{H}), 3.46-3.34$ $(\mathrm{m}, 1 \mathrm{H}), 3.14-3.01(\mathrm{~m}, 1 \mathrm{H}), 1.71(\mathrm{~s}, 3 \mathrm{H}), 1.43(\mathrm{~s}, 9 \mathrm{H}) .{ }^{13} \mathrm{C}\left\{{ }^{1} \mathrm{H}\right\}$ NMR $\left(101 \mathrm{MHz}, \mathrm{CDCl}_{3}\right): \delta 156.1,142.3,113.9,87.2,79.4,42.3$, 28.5, 18.6.

2-(aminooxy)-3-methylbut-3-en-1-amine dihydrochloride (30). According to general procedure TP6, 29 (1 eq., $100 \mathrm{mg}, 0.46$ $\mathrm{mmol})$ was treated with a hydrogen chloride solution in dioxane (4 M, $5 \mathrm{~mL}$ ) to afford 30 as a white solid $(86.6 \mathrm{mg}, 99 \%) .{ }^{1} \mathrm{H}$ NMR (400 MHz, DMSO-d $)^{6}$ : $\delta 10.90$ (s, br, 3H), 8.35 (s, br, 3H), $5.24(\mathrm{~s}, 1 \mathrm{H}), 5.22-5.19(\mathrm{~m}, 1 \mathrm{H}), 4.79(\mathrm{dd}, J=8.2,4.0 \mathrm{~Hz}, 1 \mathrm{H})$, $3.09-2.98(\mathrm{~m}, 2 \mathrm{H}), 1.72(\mathrm{~s}, 3 \mathrm{H}) .{ }^{13} \mathrm{C}\left\{{ }^{1} \mathrm{H}\right\}$ NMR $(101 \mathrm{MHz}$, DMSO- $\left.d^{6}\right): \delta 138.2,118.0,83.5, \quad 17.4$. $\left(-\mathrm{CH}_{2}-\mathrm{NH}_{2-}\right.$ signal covered by DMSO- $\left.d^{6}\right)$.

\section{6-(prop-1-en-2-yl)-5,6-dihydro-4H-1,2,4-oxadiazin-3-amine}

(31). According to general procedure TP7, 30 (1 eq., $50 \mathrm{mg}$, $0.26 \mathrm{mmol})$ in MeCN $(10 \mathrm{~mL})$ was treated successively with TEA (4 eq. $147 \mu \mathrm{L}, 1.1 \mathrm{mmol}$ ) and a solution of $\operatorname{BrCN}$ (1.1 eq., 30.8 $\mathrm{mg}, 0.29 \mathrm{mmol})$ in $\mathrm{MeCN}(0.5 \mathrm{~mL})$ to afford $31(29.9 \mathrm{mg}, 80 \%)$ as a white solid after purification by reverse phase $\mathrm{C} 18$ column chromatography $\left(\mathrm{MeCN} / \mathrm{H}_{2} \mathrm{O}\right) .{ }^{1} \mathrm{H}$ NMR $\left(400 \mathrm{MHz}\right.$, DMSO- $\left.d^{6}\right)$ : $\delta$ $6.08(\mathrm{~s}, 1 \mathrm{H}), 4.94$ (dt, $J=2.2,1.0 \mathrm{~Hz}, 1 \mathrm{H}), 4.89$ (t, $J=1.9 \mathrm{~Hz}$, $1 \mathrm{H}), 4.48(\mathrm{~s}, 2 \mathrm{H}), 3.74(\mathrm{dd}, J=9.5,3.1 \mathrm{~Hz}, 1 \mathrm{H}), 3.28(\mathrm{dd}, J=$ 11.2, $3.2 \mathrm{~Hz}, 1 \mathrm{H}$ ), 3.02 (dd, $J=11.2,9.5 \mathrm{~Hz}, 1 \mathrm{H}), 1.70(\mathrm{~s}, 3 \mathrm{H})$. ${ }^{13} \mathrm{C}\left\{{ }^{1} \mathrm{H}\right\}$ NMR $\left(101 \mathrm{MHz}\right.$, DMSO- $\left.d^{6}\right): \delta 154.1,142.4,112.0,74.3$, 43.5, 19.0. HRMS (ESI): $\mathrm{m} / \mathrm{z}$ calcd. for $\mathrm{C}_{6} \mathrm{H}_{12} \mathrm{~N}_{3} \mathrm{O}[\mathrm{M}+\mathrm{H}]^{+}$: 142.0980, found: 142.0979 .

\section{2-(3-methylbut-2-en-1-yl)-6-(prop-1-en-2-yl)-5,6-dihydro-2 $\mathrm{H}$ -}

1,2,4-oxadiazin-3-amine (32). 31 (1 eq., $10 \mathrm{mg}, 0.071 \mathrm{mmol}$ ) and TEA (2 eq., $19.7 \mu \mathrm{L}, 0.142 \mathrm{mmol}$ ) were dissolved in $\mathrm{MeCN}$ $(0.6 \mathrm{~mL}$ ), followed by the addition of prenyl bromide (1 eq., 8.3 $\mu \mathrm{L}, 0.071 \mathrm{mmol})$. The resulting mixture was stirred at $\mathrm{rt}$ for $16 \mathrm{~h}$ and then concentrated in vacuo. The crude was purified by reverse phase $\mathrm{C} 18$ column chromatography $\left(\mathrm{MeCN} / \mathrm{H}_{2} \mathrm{O}\right)$ to afford 32 as a white solid (11 mg, $74 \%)$. ${ }^{1} \mathrm{H}$ NMR $(400 \mathrm{MHz}$, DMSO-d $\left.d^{6}\right): \delta 7.65(\mathrm{~s}, 2 \mathrm{H}), 5.32-5.19(\mathrm{~m}, 1 \mathrm{H}), 5.10(\mathrm{t}, J=1.7$ $\mathrm{Hz}, 1 \mathrm{H}), 5.05$ (q, $J=1.2 \mathrm{~Hz}, 1 \mathrm{H}), 4.46(\mathrm{dd}, J=10.1,3.3 \mathrm{~Hz}, 1 \mathrm{H})$, 4.35 (dd, $J=15.9,7.2 \mathrm{~Hz}, 1 \mathrm{H}$ ), 4.17 (dd, $J=15.9,7.1 \mathrm{~Hz}, 1 \mathrm{H}$ ), $3.52(\mathrm{dt}, J=12.5,3.6 \mathrm{~Hz}, 1 \mathrm{H}), 3.36-3.29(\mathrm{~m}, 1 \mathrm{H}), 1.77-1.71$ (m, 6H), $1.68(\mathrm{~d}, J=1.3 \mathrm{~Hz}, 3 \mathrm{H}) .{ }^{13} \mathrm{C}\left\{{ }^{1} \mathrm{H}\right\} \mathrm{NMR}(101 \mathrm{MHz}$, DMSO- $\left.d^{6}\right): \delta 153.3,138.8,138.5,116.1,115.1,77.8,48.9,42.6$, 25.4, 18.8, 17.9. ${ }^{1} \mathrm{H}$ NMR $\left(400 \mathrm{MHz}, \mathrm{MeOD}-d^{4}\right): \delta 5.36-5.29(\mathrm{~m}$, $1 \mathrm{H}), 5.16-5.11(\mathrm{~m}, 1 \mathrm{H}), 5.09(\mathrm{q}, J=1.1 \mathrm{~Hz}, 1 \mathrm{H}), 4.48(\mathrm{dd}, J=$ 10.0, $3.4 \mathrm{~Hz}, 1 \mathrm{H}$ ), 4.34 (dd, $J=15.9,7.0 \mathrm{~Hz}, 1 \mathrm{H}$ ), 4.21 (dd, $J=$ 15.9, $7.5 \mathrm{~Hz}, 1 \mathrm{H}$ ), 3.54 (dd, $J=12.4,3.5 \mathrm{~Hz}, 1 \mathrm{H}$ ), 3.42 (dd, $J=$ 12.4, $10.1 \mathrm{~Hz}, 1 \mathrm{H}), 1.81(\mathrm{t}, J=1.2 \mathrm{~Hz}, 3 \mathrm{H}), 1.80(\mathrm{~d}, J=1.3 \mathrm{~Hz}$, $3 \mathrm{H}), 1.76(\mathrm{~d}, J=1.3 \mathrm{~Hz}, 3 \mathrm{H})$. HRMS (ESI): $\mathrm{m} / \mathrm{z}$ calcd. for $\mathrm{C}_{11} \mathrm{H}_{20} \mathrm{~N}_{3} \mathrm{O}[\mathrm{M}+\mathrm{H}]^{+}:$210.1606, found: 210.1606 .

\section{2-(3-methylbut-2-en-1-yl)-6-(prop-1-en-2-yl)-5,6-dihydro-2H-} 1,2, ( ${ }^{15} M$ )-oxadiazin-3-amine (33).

Step 1: tert-butyl (2-(methoxy(methyl)amino)-2oxoethyl) $\left({ }^{15} \mathrm{~N}\right)$ carbamate (45). According to general procedure TP1, ${ }^{15} \mathrm{~N}$-Boc glycine (1 eq., $500 \mathrm{mg}, 2.84 \mathrm{mmol}$ ) in DCM (15 $\mathrm{mL}$ ) was treated with CDI (1.5 eq., $690.3 \mathrm{mg}, 4.26 \mathrm{mmol}$ ), TEA (1.5 eq, $0.59 \mathrm{~mL}, 4.26 \mathrm{mmol}$ ) and N,O-dimethylhydroxylamine hydrochloride (1.5 eq., $415.3 \mathrm{~g}, 4.26 \mathrm{mmol}$ ) to afford Weinreb amide of ${ }^{15} \mathrm{~N}$-Boc glycine 45 as a white solid (543 mg, 87\%) without further purification. ${ }^{1} \mathrm{H}$ NMR $\left(400 \mathrm{MHz}, \mathrm{CDCl}_{3}\right): \delta 5.37(\mathrm{t}$, $J=5.0 \mathrm{~Hz}, 0.5 \mathrm{H}), 5.14$ (t, $J=4.9 \mathrm{~Hz}, 0.5 \mathrm{H}), 4.08(\mathrm{~d}, J=4.8 \mathrm{~Hz}$, $2 \mathrm{H}), 3.71(\mathrm{~s}, 3 \mathrm{H}), 3.20(\mathrm{~s}, 3 \mathrm{H}), 1.45(\mathrm{~s}, 9 \mathrm{H}) \cdot{ }^{13} \mathrm{C}\left\{{ }^{1} \mathrm{H}\right\} \operatorname{NMR}(101$ $\left.\mathrm{MHz}, \mathrm{CDCl}_{3}\right): \delta 170.4,156.1,155.9,79.8,61.6,41.9,41.8,32.5$, 28.5. ${ }^{15} \mathrm{~N} \mathrm{NMR}\left(51 \mathrm{MHz}, \mathrm{CDCl}_{3}\right): \delta 73.3$.

Step 2: tert-butyl (3-methyl-2-oxobut-3-en-1-yl) $\left({ }^{15} \mathrm{M}\right)$ carbamate (46). According to general procedure TP2, the above Weinreb amide of ${ }^{15} \mathrm{~N}$-Boc glycine 45 (1 eq., $543 \mathrm{mg}, 2.48 \mathrm{mmol}$ ) in THF $(5 \mathrm{~mL})$ was treated with isopropenyl magnesium bromide (3.5 eq., $0.5 \mathrm{M}, 17.3 \mathrm{~mL}, 8.67 \mathrm{mmol}$ ). The crude was purified by silica gel column chromatography (heptane:EtOAc $=5: 1$ ) to afford tert-butyl (3-methyl-2-oxobut-3-en-1-yl) $\left({ }^{15} \mathrm{~N}\right)$ carbamate (46) as a colorless oil (466 mg, 94\%). ${ }^{1} \mathrm{H}$ NMR (400 MHz, $\left.\mathrm{CDCl}_{3}\right): \delta 5.98(\mathrm{~s}, 1 \mathrm{H}), 5.82(\mathrm{q}, J=1.6 \mathrm{~Hz}, 1 \mathrm{H}), 5.47(\mathrm{t}, J=4.7$ $\mathrm{Hz}, 0.5 \mathrm{H}), 5.24(\mathrm{t}, J=4.7 \mathrm{~Hz}, 0.5 \mathrm{H}), 4.35(\mathrm{~d}, J=4.6 \mathrm{~Hz}, 2 \mathrm{H})$, $1.91-1.87(\mathrm{~m}, 3 \mathrm{H}), 1.43(\mathrm{~s}, 9 \mathrm{H}) .{ }^{13} \mathrm{C}\left\{{ }^{1} \mathrm{H}\right\}$ NMR $(101 \mathrm{MHz}$, $\left.\mathrm{CDCl}_{3}\right): \delta 196.1,156.0,155.7,142.4,125.5,79.8,46.8,46.6$, 28.5, 17.5. ${ }^{15} \mathrm{~N} \mathrm{NMR}\left(51 \mathrm{MHz}, \mathrm{CDCl}_{3}\right): \delta 72.4$.

Step 3: tert-butyl (2-hydroxy-3-methylbut-3-en-1-yl) $\left({ }^{15} \mathrm{~N}\right)$ carbamate (47). According to general procedure TP3 (method 5), the above described tert-butyl (3-methyl-2-oxobut-3en-1-yl) $\left({ }^{15} \mathrm{~N}\right.$ ) carbamate 46 (1 eq., $590 \mathrm{mg}, 2.95 \mathrm{mmol}$ ) in $\mathrm{MeOH}$ $(15 \mathrm{~mL})$ was treated with trichlorocerium heptahydrate (1.6 eq., $1.76 \mathrm{~g}, 4.71 \mathrm{mmol}$ ) and $\mathrm{NaBH}_{4}$ (1.5 eq., $167.2 \mathrm{mg}, 4.42 \mathrm{mmol}$ ). The crude was purified by silica gel column chromatography (heptane:EtOAc = 2:1) to afford tert-butyl (2-hydroxy-3methylbut-3-en-1-yl) $\left({ }^{15} \mathrm{~N}\right)$ carbamate 47 as a colorless oil (587 $\mathrm{mg}, 98 \%) .{ }^{1} \mathrm{H} \mathrm{NMR}\left(400 \mathrm{MHz}, \mathrm{CDCl}_{3}\right)$ : $\delta 5.11-4.98(\mathrm{~m}, 1.5 \mathrm{H})$, $4.91(\mathrm{dd}, J=2.5,1.4 \mathrm{~Hz}, 1 \mathrm{H}), 4.84-4.77(\mathrm{~m}, 0.5 \mathrm{H}), 4.18-4.08$ $(\mathrm{m}, 1 \mathrm{H}), 3.45-3.29(\mathrm{~m}, 1 \mathrm{H}), 3.19-3.03(\mathrm{~m}, 1 \mathrm{H}), 2.70(\mathrm{~s}, 1 \mathrm{H})$, $1.74(\mathrm{t}, J=1.2 \mathrm{~Hz}, 3 \mathrm{H}), 1.43(\mathrm{~s}, 9 \mathrm{H}) .{ }^{13} \mathrm{C}\left\{{ }^{1} \mathrm{H}\right\} \operatorname{NMR}(101 \mathrm{MHz}$, $\left.\mathrm{CDCl}_{3}\right): \delta 157.1,156.8,145.2,111.8,79.8,75.0,45.2,45.1,28.5$, 18.7. ${ }^{15} \mathrm{~N} \mathrm{NMR}\left(51 \mathrm{MHz}, \mathrm{CDCl}_{3}\right): \delta 78.4$.

Step 4: tert-butyl (2-((1,3-dioxoisoindolin-2-yl)oxy)-3-methylbut3-en-1-yl) $\left({ }^{15} \mathrm{~N}\right)$ carbamate (48). According to general procedure TP4, the above described tert-butyl (2-hydroxy-3-methylbut-3en-1-yl) ( ${ }^{15} \mathrm{~N}$ carbamate 47 (1 eq., $500 \mathrm{mg}, 2.47 \mathrm{mmol}$ ) was dissolved in THF (15 mL) and treated with NHPI (1.5 eq., 604.9 $\mathrm{mg}, 3.71 \mathrm{mmol}$ ), $\mathrm{PPh}_{3}$ (1.8 eq., $1.17 \mathrm{~g}, 4.45 \mathrm{mmol}$ ) and DEAD (1.8 eq., $0.7 \mathrm{~mL}, 4.45 \mathrm{mmol}$ ) at rt. The crude was purified by silica gel column chromatography (heptane:EtOAc $=4: 1$ ) to afford tert-butyl (2-((1,3-dioxoisoindolin-2-yl)oxy)-3-methylbut-3en-1-yl) $\left({ }^{15} \mathrm{~N}\right)$ carbamate 48 as a colorless oil $(747 \mathrm{mg}, 87 \%) .{ }^{1} \mathrm{H}$ $\operatorname{NMR}\left(400 \mathrm{MHz}, \mathrm{CDCl}_{3}\right): \delta 7.82-7.78(\mathrm{~m}, 2 \mathrm{H}), 7.76-7.72(\mathrm{~m}$, 2H), $5.54(\mathrm{t}, J=5.8 \mathrm{~Hz}, 0.5 \mathrm{H}), 5.31(\mathrm{t}, J=5.8 \mathrm{~Hz}, 0.5 \mathrm{H}), 5.04$ (dt, $J=1.6,0.9 \mathrm{~Hz}, 1 \mathrm{H}), 5.02(\mathrm{q}, J=1.6 \mathrm{~Hz}, 1 \mathrm{H}), 4.68-4.57(\mathrm{~m}$, 
1H), $3.54-3.42(\mathrm{~m}, 2 \mathrm{H}), 1.91$ (dd, $J=1.5,0.9 \mathrm{~Hz}, 3 \mathrm{H}), 1.45$ (s, $9 \mathrm{H}) .{ }^{13} \mathrm{C}\left\{{ }^{1} \mathrm{H}\right\}$ NMR $\left(101 \mathrm{MHz}, \mathrm{CDCl}_{3}\right): \delta 163.9,156.3,156.0$, 140.3, 134.6, 129.0, 123.7, 117.7, 90.6, 79.6, 42.1, 41.9, 28.5, 17.9. ${ }^{15} \mathrm{~N} \mathrm{NMR}\left(51 \mathrm{MHz}, \mathrm{CDCl}_{3}\right): \delta 77.1$.

Step 5: tert-butyl (2-(aminooxy)-3-methylbut-3-en-1-yl) $\left({ }^{15} \mathrm{~N}\right)$ carbamate (49). According to general procedure TP5, the above described tert-butyl (2-((1,3-dioxoisoindolin-2-yl)oxy)-3methylbut-3-en-1-yl) $\left({ }^{15} \mathrm{~N}\right)$ carbamate 48 (1 eq., 400 mg, 1.15 $\mathrm{mmol})$ in $\mathrm{EtOH}(15 \mathrm{~mL})$ was treated with hydrazine hydrate $(15$ eq., $0.84 \mathrm{~mL}, 17.27 \mathrm{mmol})$. The crude was purified by silica gel column chromatography (heptane:EtOAc $=2: 1$ ) to afford tertbutyl (2-(aminooxy)-3-methylbut-3-en-1-yl) $\left({ }^{15} \mathrm{~N}\right)$ carbamate 49 as a colorless oil $(210 \mathrm{mg}, 84 \%) .{ }^{1} \mathrm{H}$ NMR $\left(400 \mathrm{MHz}, \mathrm{CDCl}_{3}\right): \delta 5.33$ (s, 2H), $5.06-4.99(\mathrm{~m}, 2 \mathrm{H}), 4.95(\mathrm{dd}, J=7.6,4.6 \mathrm{~Hz}, 0.5 \mathrm{H})$, 4.72 (dd, $J=7.6,4.5 \mathrm{~Hz}, 0.5 \mathrm{H}), 4.00-3.94(\mathrm{~m}, 1 \mathrm{H}), 3.48-3.36$ $(\mathrm{m}, 1 \mathrm{H}), 3.12-3.03(\mathrm{~m}, 1 \mathrm{H}), 1.72(\mathrm{t}, J=1.2 \mathrm{~Hz}, 3 \mathrm{H}), 1.43(\mathrm{~s}$, $9 \mathrm{H}) .{ }^{13} \mathrm{C}\left\{{ }^{1} \mathrm{H}\right\}$ NMR $\left(101 \mathrm{MHz}, \mathrm{CDCl}_{3}\right): \delta 156.2,155.9,142.3$, $114.0,87.2,79.5,42.3,42.2,28.5,18.6 .{ }^{15} \mathrm{~N} \mathrm{NMR}(51 \mathrm{MHz}$, $\left.\mathrm{CDCl}_{3}\right): \delta 77.9$.

Step 6: 2-(aminooxy)-3-methylbut-3-en-1-( ${ }^{15} M$ amine dihydrochloride (50). According to general procedure TP6, the above described tert-butyl (2-(aminooxy)-3-methylbut-3-en-1-yl) $\left({ }^{15} \mathrm{~N}\right)$ carbamate 49 (1 eq., $\left.100 \mathrm{mg}, 0.46 \mathrm{mmol}\right)$ was treated with a solution of hydrochloride in dioxane $(4 \mathrm{M}, 5 \mathrm{~mL})$ to afford 2(aminooxy)-3-methylbut-3-en-1-( ${ }^{15} \mathrm{~N}$ )amine dihydrochloride $\mathbf{5 0}$ as a white solid (86.2 mg, 99\%). ${ }^{1} \mathrm{H}$ NMR $\left(400 \mathrm{MHz}\right.$, DMSO-d $\left.\mathrm{d}^{6}\right)$ : $\delta$ $10.92(\mathrm{~s}, \mathrm{br}, 3 \mathrm{H}), 8.38(\mathrm{~s}, \mathrm{br}, 3 \mathrm{H}), 5.25-5.23(\mathrm{~m}, 1 \mathrm{H}), 5.22-$ $5.19(\mathrm{~m}, 1 \mathrm{H}), 4.83-4.75(\mathrm{~m}, 1 \mathrm{H}), 3.11-2.95(\mathrm{~m}, 2 \mathrm{H}), 1.72(\mathrm{t}, J$ $=1.1 \mathrm{~Hz}, 3 \mathrm{H}) \cdot{ }^{13} \mathrm{C}\left\{{ }^{1} \mathrm{H}\right\}$ NMR $\left(101 \mathrm{MHz}, \mathrm{DMSO}-d^{6}\right): \delta$ 138.2, 118.1, 83.5, 17.4. $\left(-\mathrm{CH}_{2}-\mathrm{NH}_{2}\right.$ - signal covered by DMSO- $\left.d^{6}\right){ }^{15} \mathrm{~N}$ NMR (51 MHz, DMSO-d $\left.d^{6}\right)$ : 31.9 .

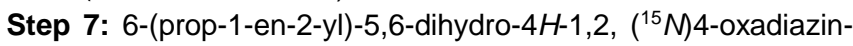
3-amine (51). According to general procedure TP7, the above described 2-(aminooxy)-3-methylbut-3-en-1-( $\left.{ }^{15} \mathrm{~N}\right)$ amine dihydrochloride 50 (1 eq., $50 \mathrm{mg}, 0.26 \mathrm{mmol}$ ) in $\mathrm{MeCN}(10 \mathrm{~mL}$ ) was treated successively with TEA (4 eq. $146 \mu \mathrm{L}, 1.05 \mathrm{mmol}$ ) and a solution of $\operatorname{BrCN}$ (1.1 eq., $30.65 \mathrm{mg}, 0.29 \mathrm{mmol}$ ) in $\mathrm{MeCN}$ $(0.5 \mathrm{~mL})$ to afford 6-(prop-1-en-2-yl)-5,6-dihydro-4H-1,2, $\left({ }^{15} \mathrm{M}\right) 4$ oxadiazin-3-amine 51 (31.8 mg, 85\%) as a white solid after purification by reverse phase $\mathrm{C} 18$ column chromatography $\left(\mathrm{MeCN} / \mathrm{H}_{2} \mathrm{O}\right)$. ${ }^{1} \mathrm{H}$ NMR $\left(400 \mathrm{MHz}, \mathrm{DMSO}-d^{6}\right): \delta 6.11(\mathrm{~s}, 0.5 \mathrm{H})$, $5.88(\mathrm{~s}, 0.5 \mathrm{H}), 4.94(\mathrm{~s}, 1 \mathrm{H}), 4.89(\mathrm{~d}, J=1.9 \mathrm{~Hz}, 1 \mathrm{H}), 4.40(\mathrm{~s}, 2 \mathrm{H})$ 3.72 (dd, $J=9.6,3.0 \mathrm{~Hz}, 1 \mathrm{H}$ ), 3.28 (dd, $J=11.5,3.2 \mathrm{~Hz}, 1 \mathrm{H}$ ), 3.01 (t, $J=10.3 \mathrm{~Hz}, 1 \mathrm{H}), 1.69(\mathrm{~s}, 3 \mathrm{H}) .{ }^{13} \mathrm{C}\left\{{ }^{1} \mathrm{H}\right\} \operatorname{NMR}(101 \mathrm{MHz}$, DMSO- $\left.d^{6}\right): \delta 154.2,154.0,142.5,111.9,74.2,43.6,43.5,19.0$. ${ }^{15} \mathrm{~N}$ NMR $\left(51 \mathrm{MHz}, \mathrm{DMSO}-d^{6}\right): \delta 60.8$.

Step 8: 2-(3-methylbut-2-en-1-yl)-6-(prop-1-en-2-yl)-5,6-dihydro-

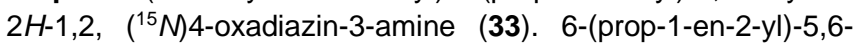

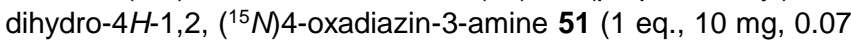
$\mathrm{mmol}$ ) and TEA (2 eq., $19.6 \mu \mathrm{L}, 0.141 \mathrm{mmol}$ ) were dissolved in MeCN $(0.6 \mathrm{~mL})$, followed by the addition of prenyl bromide (1 eq., $8.3 \mu \mathrm{L}, 0.07 \mathrm{mmol})$. The resulting mixture was stirred at $\mathrm{rt}$ for $16 \mathrm{~h}$ and concentrated in vacuo. The crude was purified by reverse phase $\mathrm{C} 18$ column chromatography $\left(\mathrm{MeCN} / \mathrm{H}_{2} \mathrm{O}\right)$ to afford 33 as a white solid (12 mg, $81 \%)$. ${ }^{1} \mathrm{H}$ NMR $(400 \mathrm{MHz}$, DMSO-d $\left.d^{6}\right): \delta 7.96(\mathrm{~s}, 2 \mathrm{H}), 5.30-5.22(\mathrm{~m}, 1 \mathrm{H}), 5.09(\mathrm{t}, J=1.7$ $\mathrm{Hz}, 1 \mathrm{H}), 5.04$ (q, $J=1.2 \mathrm{~Hz}, 1 \mathrm{H}), 4.44(\mathrm{dd}, J=10.1,3.3 \mathrm{~Hz}, 1 \mathrm{H})$, $4.34(\mathrm{dd}, J=15.9,7.2 \mathrm{~Hz}, 1 \mathrm{H}), 4.16(\mathrm{dd}, J=15.9,7.1 \mathrm{~Hz}, 1 \mathrm{H})$, $3.54-3.47(\mathrm{~m}, 1 \mathrm{H}), 3.36-3.28(\mathrm{~m}, 1 \mathrm{H}), 1.76-1.71(\mathrm{~m}, 6 \mathrm{H})$, $1.68(\mathrm{~d}, J=1.3 \mathrm{~Hz}, 3 \mathrm{H}) .{ }^{13} \mathrm{C}\left\{{ }^{1} \mathrm{H}\right\}$ NMR $\left(101 \mathrm{MHz}, \mathrm{DMSO}-d^{6}\right): \delta$ 153.4, 153.2, 138.7, 138.6, 116.2, 115.0, 77.7, 48.9, 42.7, 42.7, $25.4,18.8,17.9 .{ }^{15} \mathrm{~N}$ NMR (51 MHz, DMSO- $\left.d^{6}\right): \delta 83.6{ }^{1} \mathrm{H}$ NMR $\left(400 \mathrm{MHz}, \mathrm{MeOD}-\mathrm{d}^{4}\right): \delta 5.37-5.29(\mathrm{~m}, 1 \mathrm{H}), 5.14(\mathrm{dd}, J=1.7$, $0.9 \mathrm{~Hz}, 1 \mathrm{H}$ ), 5.09 (q, $J=1.1 \mathrm{~Hz}, 1 \mathrm{H}$ ), 4.48 (dd, $J=10.1,3.5 \mathrm{~Hz}$,
$1 \mathrm{H}), 4.34$ (dd, $J=15.9,7.0 \mathrm{~Hz}, 1 \mathrm{H}), 4.22(\mathrm{dd}, J=15.9,7.5 \mathrm{~Hz}$, 1H), 3.55 (ddd, $J=12.4,3.5,1.2 \mathrm{~Hz}, 1 \mathrm{H}$ ), 3.42 (dd, $J=12.4$ $10.1 \mathrm{~Hz}, 1 \mathrm{H}), 1.81(\mathrm{t}, J=1.3 \mathrm{~Hz}, 3 \mathrm{H}), 1.80(\mathrm{~d}, J=1.3 \mathrm{~Hz}, 3 \mathrm{H})$, $1.76(\mathrm{~d}, J=1.3 \mathrm{~Hz}, 3 \mathrm{H})$. HRMS $(\mathrm{ESI}): \mathrm{m} / \mathrm{z}$ calcd. for $\mathrm{C}_{11} \mathrm{H}_{20} \mathrm{~N}_{2}{ }^{15} \mathrm{NO}[\mathrm{M}+\mathrm{H}]^{+}: 211.1577$, found: 211.1578 .

Tert-butyl 3-amino-6-(prop-1-en-2-yl)-5,6-dihydro-2H-1,2,4oxadiazine-2-carboxylate (34). TEA (2 eq., $39.4 \mu \mathrm{L}, 0.283$ $\mathrm{mmol}$ ) was added to a solution of 31 (1 eq., $20 \mathrm{mg}, 0.142 \mathrm{mmol}$ ) and $\mathrm{Boc}_{2} \mathrm{O}$ (1.1 eq., $34 \mathrm{mg}, 0.156 \mathrm{mmol}$ ) in DCM (1 mL). The mixture was stirred at $\mathrm{rt}$ for $16 \mathrm{~h}$ and concentrated in vacuo. The crude was purified by reverse phase $\mathrm{C} 18$ column chromatography $\left(\mathrm{MeOH} / \mathrm{H}_{2} \mathrm{O}\right)$ to afford 34 as a white solid (31 $\mathrm{mg}, 91 \%$ ). ${ }^{1} \mathrm{H}$ NMR $\left(400 \mathrm{MHz}, \mathrm{CDCl}_{3}\right.$ ): $\delta 5.32$ (s, 2H), 5.03 (q, J $=1.1 \mathrm{~Hz}, 1 \mathrm{H}), 5.01-4.99(\mathrm{~m}, 1 \mathrm{H}), 4.11(\mathrm{dd}, J=10.3,3.0 \mathrm{~Hz}$, $1 \mathrm{H}$ ), 3.81 (dd, $J=12.0,3.1 \mathrm{~Hz}, 1 \mathrm{H}$ ), 3.51 (dd, $J=12.0,10.3 \mathrm{~Hz}$, $1 \mathrm{H}), 1.79(\mathrm{t}, J=1.3 \mathrm{~Hz}, 3 \mathrm{H}), 1.50(\mathrm{~s}, 9 \mathrm{H}) .{ }^{13} \mathrm{C}\left\{{ }^{1} \mathrm{H}\right\}$ NMR $(101$ $\left.\mathrm{MHz}, \mathrm{CDCl}_{3}\right): \delta 151.8,150.7,140.6,114.2,84.0,76.6,48.4$, 28.2, 19.2. HRMS (ESI): $\mathrm{m} / \mathrm{z}$ calcd. for $\mathrm{C}_{11} \mathrm{H}_{19} \mathrm{~N}_{3} \mathrm{O}_{3}[\mathrm{M}-\mathrm{Boc}+$ $\mathrm{H}^{+}:$: 142.0980, found: 142.0980 .

Tert-butyl 3-((3-methylbut-2-en-1-yl)amino)-6-(prop-1-en-2yl)-5,6-dihydro-2H-1,2,4-oxadiazine-2-carboxylate (35). A solution of $\mathrm{NaH}$ (4 eq., $4.61 \mathrm{mg}, 0.182 \mathrm{mmol}$ ) in THF $(0.4 \mathrm{~mL})$ was slowly added to a solution of 34 (1 eq., $11 \mathrm{mg}, 0.046 \mathrm{mmol}$ ) in THF $(0.7 \mathrm{~mL})$ under Ar at rt. The mixture was stirred at $60^{\circ} \mathrm{C}$ in an oil bath for $1 \mathrm{~h}$ and then a solution of prenyl bromide (4 eq., $21.4 \mu \mathrm{L}, 0.182 \mathrm{mmol})$ in THF $(0.1 \mathrm{~mL})$ was added dropwise and stirred at $60{ }^{\circ} \mathrm{C}$ in an oil bath for an additional $4 \mathrm{~h}$. The reaction mixture was concentrated in vacuo and purified by reverse phase $\mathrm{C} 18$ column chromatography $\left(\mathrm{MeCN} / \mathrm{H}_{2} \mathrm{O}\right)$ to afford $\mathbf{3 5}$ as a white solid (10.7 mg, $76 \%)$. ${ }^{1} \mathrm{H}$ NMR $\left(400 \mathrm{MHz}, \mathrm{CDCl}_{3}\right): \delta 6.65$ $(\mathrm{s}, 1 \mathrm{H}), 5.34-5.24(\mathrm{~m}, 1 \mathrm{H}), 5.07-4.93(\mathrm{~m}, 2 \mathrm{H}), 4.11(\mathrm{~d}, J=$ $10.6 \mathrm{~Hz}, 1 \mathrm{H}), 3.81(\mathrm{dd}, J=11.9,3.1 \mathrm{~Hz}, 1 \mathrm{H}), 3.70-3.60(\mathrm{~m}$, $2 \mathrm{H}), 3.57-3.48(\mathrm{~m}, 1 \mathrm{H}), 1.81(\mathrm{~s}, 3 \mathrm{H}), 1.72(\mathrm{~s}, 3 \mathrm{H}), 1.66(\mathrm{~s}, 3 \mathrm{H})$, $1.51(\mathrm{~s}, 9 \mathrm{H}) .{ }^{13} \mathrm{C}\left\{{ }^{1} \mathrm{H}\right\}$ NMR $\left(101 \mathrm{MHz}, \mathrm{CDCl}_{3}\right): \delta 162.3,150.5$, 141.0, 138.9, 120.9, 113.7, 83.7, 76.5, 48.8, 39.9, 29.9, 28.3, 25.8, 19.2. HRMS (ESI): $\mathrm{m} / \mathrm{z}$ calcd. for $\mathrm{C}_{16} \mathrm{H}_{27} \mathrm{~N}_{3} \mathrm{O}_{3}[\mathrm{M}-\mathrm{Boc}+$ $\mathrm{H}^{+}:$:210.1606, found: 210.1615 .

\section{ASSOCIATED CONTENT}

The Supporting Information is available free of charge on the ACS Publications website.

NMR studies about BrCN-mediated cyclization, diastereoselective reduction of ketone by DIBAL-H ${ }^{1} \mathrm{H},{ }^{13} \mathrm{C}$ NMR spectra, Mitsunobu reaction with inversion of configuration, synthetic pathways and NMR characterization of cpd 22, 33, NMR and HRMS comparison between 1 and data from Barrosa et al. ${ }^{14}$ Experimental procedures for LogD determination and metabolic stabilities. ${ }^{1} \mathrm{H}$ and ${ }^{13} \mathrm{C}$ NMR for all new compounds. FAIR Data is available as Supporting Information for Publication and includes the primary NMR FID files for compounds $[\mathbf{1}, \mathbf{8}$, 19a, 19b, 20a, 20b, 21]

Deposition Numbers CCDC 2007599-2007601 contains the supplementary crystallographic data for this paper. These data can be obtained free of charge from The Cambridge Crystallographic Data Centre via www.ccdc.cam.ac.uk/structures

\section{AUTHOR INFORMATION}

\section{Corresponding Author}


Frédéric Bihel - Laboratoire d'Innovation Thérapeutique, UMR7200, CNRS, Université de Strasbourg, Faculty of Pharmacy, 74 Route du Rhin, 67401 Illkirch-Graffenstaden, France ; http://orcid.org/0000-0002-4122-0929; Tel: +33 (0)368854130 ; email: fbihel@unistra.fr

\section{CONFLICTS OF INTEREST}

The authors declare no conflict of interest.

\section{ACKNOWLEDGMENT}

We gratefully acknowledge the Ministry of Education of the P.R. China for financial support of this work (PhD grant for S-Q T, China Scholarship Council (201608310124)).

\section{REFERENCES}

1. Vo, C. V.; Bode, J. W., Synthesis of saturated N-heterocycles. J. Org. Chem. 2014, 79, 2809-15.

2. Zhersh, S. A.; Blahun, O. P.; Sadkova, I. V.; Tolmachev, A. A.; Moroz, Y. S.; Mykhailiuk, P. K., Saturated Heterocyclic Aminosulfonyl Fluorides: New Scaffolds for Protecting-Group-Free Synthesis of Sulfonamides. Chem. Eur. J. 2018, 24, 8343-8349.

3. Kumar, S.; Thornton, P. D.; Painter, T. O.; Jain, P.; Downard, J.; Douglas, J. T.; Santini, C., Synthesis of a Family of Spirocyclic Scaffolds: Building Blocks for the Exploration of Chemical Space. J. Org. Chem. 2013, 78, 6529-6539.

4. O'Boyle, N. M.; Barrett, I.; Greene, L. M.; Carr, M.; Fayne, D.; Twamley, B.; Knox, A. J. S.; Keely, N. O.; Zisterer, D. M.; Meegan, M. J., Lead Optimization of Benzoxepin-Type Selective Estrogen Receptor (ER) Modulators and Downregulators with SubtypeSpecific ERa and ERß Activity. J. Med. Chem. 2018, 61, 514-534. 5. Zhang, J.; Hao, W.; Zhorov, B. S.; Dong, K.; Jiang, D., Discovery of a Novel Series of Tricyclic Oxadiazine 4a-Methyl Esters Based on Indoxacarb as Potential Sodium Channel Blocker/Modulator Insecticides. J. Agric. Food Chem. 2019, 67, 7793-7809.

6. Eissa, F. M., Green Synthesis, Antibacterial, and Antifungal Activities of 1,3,4-Oxadiazines. J. Heterocycl. Chem. 2018, 55, 1479-1483.

7. Berthet, M.; Legrand, B.; Martinez, J.; Parrot, I., A General Approach to the Aza-Diketomorpholine Scaffold. Org. Lett. 2017, 19, 492-495.

8. Lee, J.; Lee, Y.; Park, S. J.; Lee, J.; Kim, Y. S.; Suh, Y.-G.; Lee, J., Discovery of highly selective and potent monoamine oxidase $B$ inhibitors: Contribution of additional phenyl rings introduced into 2aryl-1,3,4-oxadiazin-5(6H)-one. Eur. J. Med. Chem. 2017, 130, 365378.

9. Ke, S.; Cao, X.; Liang, Y.; Wang, K.; Yang, Z., Synthesis and Biological Properties of Dihydro-Oxadiazine-Based Heterocyclic Derivatives. Mini-Rev. Med. Chem. 2011, 11, 642-657.

10. Abele, E.; Abele, R.; Golomba, L.; Višṇevska, J.; Beresneva, T.; Rubina, K.; Lukevics, E., Oximes of six-membered heterocyclic compounds with two and three heteroatoms. II. * Reactions and biological activity. Chem. Heterocycl. Compd. 2010, 46, 905-930. 11. Lovering, F.; Bikker, J.; Humblet, C., Escape from flatland: increasing saturation as an approach to improving clinical success. J. Med. Chem. 2009, 52, 6752-6.

12. Lovering, F., Escape from Flatland 2: complexity and promiscuity. MedChemComm 2013, 4, 515-519.
13. Thomas, D. A.; Rosenthal, G. A., Toxicity and pharmacokinetics of the nonprotein amino acid I-canavanine in the rat. Toxicol. Appl. Pharmacol. 1987, 91, 395-405.

14. Barrosa, K. H.; Pinto, E. G.; Tempone, A. G.; Martins, E. G.; Lago, J. H., Alchornedine, a new anti-trypanosomal guanidine alkaloid from Alchornea glandulosa. Planta Med. 2014, 80, 1310-4. 15. G. Bursavich, M.; J. N. Veerman, J.; B. Bruseker, Y.; C. J. van Esseveldt, B.; Glen, R.; A. Harrison, B.; H. Heijne, E.; J. McRiner, A.; M. Meulemans, T.; van Rijnsbergen, P.; Zonneveld, W.; A. Burnett, D., Strategic and Tactical Approaches to the Synthesis of 5,6Dihydro-[1,2,4]oxadiazines. Heterocycles 2016, 92, 2166-2220.

16. Shetnev, A. A.; Zubkov, F. I., The latest advances in chemistry of 1,2,4-oxadiazines. Chem. Heterocycl. Compd. 2017, 53, 495-497. 17. Pathipati, S. R.; Singh, V.; Eriksson, L.; Selander, N., Lewis Acid Catalyzed Annulation of Nitrones with Oxiranes, Aziridines, and Thiiranes. Org. Lett. 2015, 17, 4506-9.

18. Oukoloff, K.; Kovalevich, J.; Cornec, A.-S.; Yao, Y.; Owyang, Z. A.; James, M.; Trojanowski, J. Q.; Lee, V. M. Y.; Smith, A. B.; Brunden, K. R.; Ballatore, C., Design, synthesis and evaluation of photoactivatable derivatives of microtubule (MT)-active [1,2,4]triazolo[1,5-a]pyrimidines. Bioorg. Med. Chem. Lett. 2018, 28 , 2180-2183.

19. Kasamatsu, K.; Yoshimura, T.; Mandi, A.; Taniguchi, T.; Monde, K.; Furuta, T.; Kawabata, T., a-Arylation of a-Amino Acid Derivatives with Arynes via Memory of Chirality: Asymmetric Synthesis of Benzocyclobutenones with Tetrasubstituted Carbon. Org. Lett. 2017, 19, 352-355.

20. Ripa, L.; Edman, K.; Dearman, M.; Edenro, G.; Hendrickx, R.; Ullah, V.; Chang, H.-F.; Lepistö, M.; Chapman, D.; Geschwindner, S.; Wissler, L.; Svanberg, P.; Lawitz, K.; Malmberg, J.; Nikitidis, A.; Olsson, R. I.; Bird, J.; Llinas, A.; Hegelund-Myrbäck, T.; Berger, M.; Thorne, P.; Harrison, R.; Köhler, C.; Drmota, T., Discovery of a Novel Oral Glucocorticoid Receptor Modulator (AZD9567) with Improved Side Effect Profile. J. Med. Chem. 2018, 61, 1785-1799. 21. Giltrap, A. M.; Haeckl, F. P. J.; Kurita, K. L.; Linington, R. G.; Payne, R. J., Synthetic Studies Toward the Skyllamycins: Total Synthesis and Generation of Simplified Analogues. J. Org. Chem. 2018, 83, 7250-7270.

22. Trost, B. M.; Tracy, J. S.; Saget, T., Direct catalytic enantioselective amination of ketones for the formation of tri- and tetrasubstituted stereocenters. Chem. Sci. 2018, 9, 2975-2980. 23. Ohsawa, K.; Sugai, M.; Zhang, L.; Masuda, Y.; Yoshida, M.; Doi, T., Total Synthesis and Structural Revision of Cyclotetrapeptide Asperterrestide A. J. Org. Chem. 2019, 84, 6765-6779.

24. Helal, C. J.; Meyer, M. P., The Corey-Bakshi-Shibata Reduction: Mechanistic and Synthetic Considerations - Bifunctional Lewis Base Catalysis with Dual Activation. In Lewis Base Catalysis in Organic Synthesis, 2016; pp 387-456.

25. Swamy, K. C. K.; Kumar, N. N. B.; Balaraman, E.; Kumar, K. V. P. P., Mitsunobu and Related Reactions: Advances and Applications. Chem. Rev. 2009, 109, 2551-2651.

26. Benet, L. Z.; Hosey, C. M.; Ursu, O.; Oprea, T. I., BDDCS, the Rule of 5 and drugability. Adv. Drug Delivery Rev. 2016, 101, 89-98. 27. Weinhardt, K.; Wallach, M. B.; Marx, M., Synthesis and antidepressant profiles of phenyl-substituted 2-amino- and 2[(alkoxycarbonyl)amino]-1,4,5,6-tetrahydropyrimidines. J. Med. Chem. 1985, 28, 694-698.

28. Baskaran, S.; Hanan, E.; Byun, D.; Shen, W., A facile reduction of 2-aminopyrimidines with triethylsilane and trifluoroacetic acid. Tetrahedron Lett. 2004, 45, 2107-2111.

29. Nguyen, P. h.; Hammoud, H.; Halliez, S.; Pang, Y.; Evrard, J.; Schmitt, M.; Oumata, N.; Bourguignon, J.-J.; Sanyal, S.; Beringue, V.; Blondel, M.; Bihel, F.; Voisset, C., Structure-Activity Relationship Study around Guanabenz Identifies Two Derivatives Retaining 
Antiprion Activity but Having Lost a2-Adrenergic Receptor Agonistic Activity. ACS Chem. Neurosci. 2014, 5, 1075-1082.

30. Hammoud, H.; Elhabazi, K.; Quillet, R.; Bertin, I.; Utard, V.; Laboureyras, E.; Bourguignon, J.-J.; Bihel, F.; Simonnet, G.;

Simonin, F.; Schmitt, M., Aminoguanidine Hydrazone Derivatives as Nonpeptide NPFF1 Receptor Antagonists Reverse Opioid Induced Hyperalgesia. ACS Chem. Neurosci. 2018, 9, 2599-2609.

31. Dai, N.; Wang, X. J.; Etzkorn, F. A., The Effect of a Trans-

Locked Gly-Pro Alkene Isostere on Collagen Triple Helix Stability. J. Am. Chem. Soc. 2008, 130, 5396-5397.

32. Hirayama, T.; Ishikawa, T.; Okaniwa, M.; Kakei, H.; Banno, H.; Yokota, A., Preparation of N,N-dialkylimidazo[1,2-a]pyridine-2carboxamide derivatives as anticancer agents. WO 2012008508 A1 2012.

33. Johnson, E. P.; Hubieki, M. P.; Combs, A. P.; Teleha, C. A., Preparation of $\alpha$-Hydroxy- $\beta$-Fmoc Amino Acids from N-Boc Amino Acids. Synthesis 2011, 2011, 4023-4026.

34. Lauber, M. B.; Stahl, S. S., Efficient Aerobic Oxidation of Secondary Alcohols at Ambient Temperature with an ABNO/NOx Catalyst System. ACS Catal. 2013, 3, 2612-2616.

35. King, A. M.; De Ryck, M.; Kaminski, R.; Valade, A.; Stables, J. P.; Kohn, H., Defining the Structural Parameters That Confer Anticonvulsant Activity by the Site-by-Site Modification of (R)-N'Benzyl 2-Amino-3-methylbutanamide. J. Med. Chem. 2011, 54, 6432-6442.

36. Garcia, J.; Mata, E. G.; Tice, C. M.; Hormann, R. E.; Nicolas, E.; Albericio, F.; Michelotti, E. L., Evaluation of Solution and SolidPhase Approaches to the Synthesis of Libraries of $\alpha, \alpha$-Disubstituteda-acylaminoketones. J. Comb. Chem. 2005, 7, 843-863.

37. Kong, C.; Jana, N.; Driver, T. G., Rh2(II)-Catalyzed Selective Aminomethylene Migration from Styryl Azides. Org. Lett. 2013, 15, 824-827.

38. Guo, R.; Lu, S.; Chen, X.; Tsang, C.-W.; Jia, W.; Sui-Seng, C.; Amoroso, D.; Abdur-Rashid, K., Synthesis of Chiral

Aminophosphines from Chiral Aminoalcohols via Cyclic Sulfamidates. J. Org. Chem. 2010, 75, 937-940.

39. Lee, H.-K.; Kang, S.; Choi, E. B., Stereoselective Synthesis of Norephedrine and Norpseudoephedrine by Using Asymmetric Transfer Hydrogenation Accompanied by Dynamic Kinetic Resolution. J. Org. Chem. 2012, 77, 5454-5460.

40. Schmidt, F.; Keller, F.; Vedrenne, E.; Aggarwal, V. K., Stereocontrolled Synthesis of $\beta$-Amino Alcohols from Lithiated Aziridines and Boronic Esters. Angew. Chem., Int. Ed. Engl. 2009, 48, 1149-1152.

41. Bilke, J. L.; Moore, S. P.; O’Brien, P.; Gilday, J., Catalytic Asymmetric Synthesis of Piperidines from Pyrrolidine: Concise Synthesis of L-733,060. Org. Lett. 2009, 11, 1935-1938.

42. Büchi, G.; Rodriguez, A. D.; Yakushijin, K. Syntheses of ( \pm )Alchorneine and ( \pm )-Isoalchorneine. J. Org. Chem. 1989, 54, 44944496 